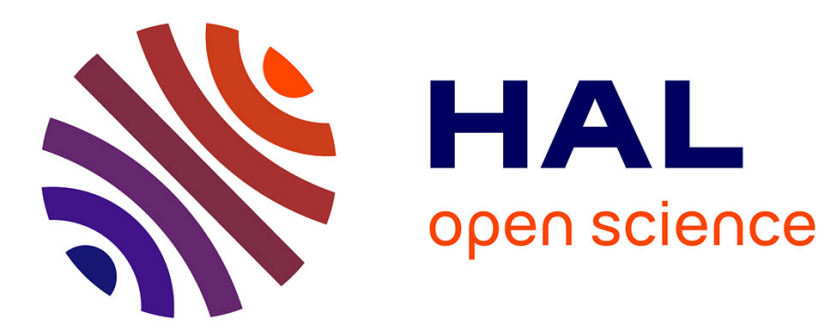

\title{
The Bronze and Iron Age Pottery from Sovjan
}

\author{
Maja Gori, Tobias Krapf
}

\section{To cite this version:}

Maja Gori, Tobias Krapf. The Bronze and Iron Age Pottery from Sovjan. Iliria, 2015, 39, pp.91 - 135. 10.3406/iliri.2015.2500 . halshs-03208442

\section{HAL Id: halshs-03208442 https://shs.hal.science/halshs-03208442}

Submitted on 13 Sep 2021

HAL is a multi-disciplinary open access archive for the deposit and dissemination of scientific research documents, whether they are published or not. The documents may come from teaching and research institutions in France or abroad, or from public or private research centers.
L'archive ouverte pluridisciplinaire HAL, est destinée au dépôt et à la diffusion de documents scientifiques de niveau recherche, publiés ou non, émanant des établissements d'enseignement et de recherche français ou étrangers, des laboratoires publics ou privés. 


\section{The Bronze and Iron Age Pottery from Sovjan}

Maja Gori, Tobias Krapf

\section{Citer ce document / Cite this document :}

Gori Maja, Krapf Tobias. The Bronze and Iron Age Pottery from Sovjan. In: Iliria, vol. 39, 2015. pp. 91-135;

doi : https://doi.org/10.3406/iliri.2015.2500

https://www.persee.fr/doc/iliri_1727-2548_2015_num_39_1_2500

Fichier pdf généré le 18/01/2019 


\section{Maja GORI, Tobias KRAPF}

\section{THE BRONZE AND IRON AGE POTTERY FROM SOVJAN ${ }^{1}$}

\section{Introduction}

Sovjan is located in southeast Albania, on the northwestern side of the approximately $250 \mathrm{~km}^{2}$ large Korça Plain, a wide plateau forming one of the typical inland basins distinctive of the Balkans. Sovjan is a 1.5 ha lakeside settlement, situated on the western shores of what had been Lake Maliq until it was drained during the 1940's. It lies some $3.5 \mathrm{~km}$ northeast of the modern village of Maliq, whose prehistoric site of the same name was discovered in 1948. ${ }^{2}$ In 1988, much like Maliq, Sovjan was discovered by chance, during intense agricultural work on the plain.

The elliptically shaped site measures $120 \mathrm{~m}$ (east to west) x $160 \mathrm{~m}$ (north to south) and lies approximately $2 \mathrm{~m}$ above the surrounding plain at an altitude of $817.5 \mathrm{~m}$ a.s.l.

1 This study has been undertaken in the frame of the "Mission franco-albanaise du Bassin de Korçë", directed by P. Lera, G. Touchais and C. Oberweiler. We would like to express our deep gratitude to the directors of the project for allowing us to study the pottery from Sovjan, and for their support and help in Korçë. We owe special thanks to Petrika Lera for sharing with us his wide and profound knowledge of the Korçë region. The drawings were made by the authors. M. Bénet made most of the digital re-drawings of plates 7-12. The research has been supported by DAAD, Janggen-Pöhn-Stiftung, Swiss National Science Foundation, and Université francoallemande Deutsch-Französische Hochschule.

2 Prendi (1966). 
Sovjan can be considered a tell, despite it is not rising very high above the surrounding landscape, which differed significantly during the site's occupation. While Sovjan is not a pile dwelling settlement in the strict sense of the term, it can be considered a lakeside settlement built on a marsh shore with wooden platforms used to pave the muddy surface, where at least part of the village was built. Its distance to the lake varied according to the periods. The preservation of the site's material remains is exceptional. Due to the former lake and marsh environment, the high water table produced favourable anaerobic conditions for the preservation of a wide range of organic remains. Apart from the trenches connected to the digging of modern irrigation canals and to some agricultural damage affecting the upper levels, very little disturbance of the archaeological deposits can be noted.

P. Lera (Institute of Archaeology, Tirana) carried out several test excavations at Sovjan between 1988 and 1991. ${ }^{3}$ More extensive excavations were resumed in 1993 as part of a collaborative project involving the Institute of Archaeology in Tirana and the École française d'Athènes - Unité de Recherche de Protohistoire égéenne (GNRS - Université de Paris 1) under the direction of R. Treuil and F. Prendi, then G. Touchais and P. Lera (2000-2006). Fieldwork continued without interruption until 2006, with only a brief hiatus in 1997 and 1998. ${ }^{4}$ From 2007 onwards, research was devoted entirely to the study of movable and non-movable remains, combined with a targeted survey project (PALM - Prospection Archéologique du paléo-Lac Maliq) focusing on the northern part of the Korçë basin around the ancient lake Maliq, in order to get a better understanding of the prehistoric landscape in which the site was located. ${ }^{5}$

\section{Chronology}

The stratigraphic sequence of Sovjan ranges from Early Neolithic to Iron Age. It is currently the only site of the second half of the Early Bronze Age (EBA) in the southwestern Balkans for which a substantial number of radiocarbon dates and dendrochronology are available. Level ${ }^{6} 14$ is the sterile layer below the lowest anthropic deposits. Levels 13 and 12,

3 Lera (1990).

4 Preliminary reports in BCH 118, $1994-131,2007$.

5 Preliminary reports in BCH 132, 2008 - 137, 2013.

6 In this work we use the term "level" to indicate a coherent ensemble of stratigraphic units (i.e. layers) grouped together on the basis of homogeneous stratigraphic and chronological characteristics. The term level is here used as alternative to the term phase, since the final publication of the excavation with the final denomination of the phases is still in preparation. 
both dated to the Early Neolithic, are believed to be the site's earliest occupation horizons. ${ }^{7}$ The wooden feature documented from level 13 is the earliest architectural structure from Sovjan known to this day. The clayey, light grey level 12 is archeologically sterile. As some wooden elements were found at the interface between level 12 and level 11, the two layers seem likely to be closely related. Level 12 is interpreted as a deposit possibly representing the temporary abandonment of the settlement, perhaps due to a relocation of the dwellings to another area of the site. Level 11 was reached for the first time during the 2001 field season. In most sectors, the upper surface of level 11 consists of a fine layer of carbonised material containing potsherds, one of which was decorated with barbotine. Fingernail impressed greyblack monochrome potsherds and one pierced hemispherical handle, both common in the Early and Middle Neolithic, were found in sector B $1 .^{8}$ Also associated with this layer are wooden features, but they are very difficult to interpret due to the limited extent of the investigated surface. Level 10 lacks archaeological material. At present, the assignment of this level to the Late Neolithic or the beginning of Early Bronze Age remains tentative.

Level 9 is the most ancient level belonging to the Bronze Age discovered so far within the site. A deep test pit was excavated in 1999 named sondage profond, and in 2001, new sectors were opened at the base of the artificial canal. Numerous artefacts were recovered from these new sectors, ultimately leading to a revision of its original interpretation. Only one radiocarbon date is available for level 9, dating it to $3935 \pm 30 \mathrm{BP} / 2486$ to $2204 \mathrm{BCE} .^{9}$ This date roughly corresponds to Mandalo phase III, Argissa Magoula Early EB3 and Sitagroi Vb. ${ }^{10}$ Together with data from Sovjan, the new radiocarbon dates from Vreshtasi obtained in the framework of the PALM project are contributing to a better definition of the chronology of the earlier phases of the EBA in southern Albania (3332 to 2916 and 3078 to 2883 BCE). ${ }^{11}$

Level 8 is composed of a brown clayey peat layer rich in organic material. Several wooden plankings were discovered, allowing for dendrochronological analysis, however only

7 Lera - Touchais (2003) pp. 599-603. The Neolithic period in the Balkans does not begin until about 6000 BCE. Despite the absence of pottery, the wooden elements suggest the existence of a sedentary settlement at this early date. For this reason level 13 is believed to represent the beginnings of the Early Neolithic, even though the two available radiocarbon dates are about 500 years older than the earliest dates for the beginnings of Neolithic culture in the Balkans and Northern Greece. See also Allen - Gjipali (2014) especially pp. 108-109 and tab. 1.

8 Lera - Touchais (2003) fig. 30. Periods according to the terminology used in Albania.

9 Lera - Touchais (2003) p. 606.

10 Manning (1995) p. 180; Kotsakis et al. (1989) pp. 682-683; Maniatis - Kromer (1990) p. 151.

11 Oberweiler - Touchais - Lera (2014) pp. 89-90. 
one radiocarbon date is available for this level, dating it to $3765 \pm 45 \mathrm{BP} / 2303$ to 2040 BCE. ${ }^{12}$ In 2002, the excavation sectors were unified uncovering a wide wattle and daub wall to be securely identified as the perimeter wall of a wide pile-dwelling structure ${ }^{13}$ referred to as the Maison du Canal. Level 8 contains the most impressive and well-preserved wooden piledwelling structures dated to the EBA currently known from the southwestern Balkans. ${ }^{14}$ The Maison du Canal is oriented north-south and measures more than $15 \mathrm{~m}$ in length and $4 \mathrm{~m}$ in width. It lies parallel to the artificial canal that cut the settlement in two and from which it derives its name. ${ }^{15}$ About 2 m north of the Maison du Canal, an east-west-oriented wooden planking (chemin de rondins), constructed out of round beams and placed on a long traverse has been interpreted as a trackway ${ }^{16}$ connected to a further dwelling structure called the Maison $d u$ Pêcheur. The archaeological remains suggest the existence of a system of wooden paths and tracks connecting the various village households.

The limit between levels 7 and 8 is generally fairly clear, unlike the interface between levels 6 and 7, which in some points appears not well-defined. ${ }^{17}$ In comparison to level 8, very few features from level 7 were identified: two ovens/hearths and traces of a dwelling structure referred to as the Maison Effondrée. The precise chronology of level 7 is somewhat problematic. In fact, one date (4035 $\pm 55 \mathrm{BP} / 2843$ to $2416 \mathrm{BCE})$ is identical to or perhaps even older than the radiocarbon date available for level 9, while the other dates from level 7 are comparable to the single radiocarbon date from level 8 . There are five radiocarbon dates available for level 7, dating it to between 2300 to 1950 BCE. Level 7 appears roughly contemporaneous with Archontiko phase B, which is composed of several building phases (II, III, IV) dated to between 2300 and $1900 \mathrm{BCE},{ }^{18}$ and must therefore be located at the end of the EBA and at the beginning of MBA.

The nature of level 6 is more difficult to understand. It corresponds to a layer of levelling and filling preceding the installation of floor level S4 and layer 5c3 of the Late Bronze Age $(\mathrm{LBA})^{19}$ that doesn't show a homogenous texture and colour in all sectors of the site. ${ }^{20}$ The two available radiocarbon dates from the bottom of level 6 overlap with

12 Lera - Touchais (1997) p. 874.

13 Lera - Touchais (2003) pp. 590-591 fig. 11 and 12.

14 Lera - Touchais (2004) pp. 32-34.

15 Lera - Touchais (2003) pp. 589-590.

16 Lera - Touchais (2002) p. 634 fig. 8; Id. (2003) p. 591.

17 Lera - Touchais (2004-5) p. 1128.

18 Papaefthimiou Papanthimou - Pilali Papasteriou (2002) p. 311 fig. 1.

19 Lera - Touchais - Oberweiler (2009) pp. 711-712.

20 Lera - Touchais (2004-5) p. 1123. 
level 7 (2200-1920 BCE and 2287-1981 BCE). ${ }^{21}$ Although the pottery shapes still pertain to the traditions of level 7, there is a technological change and the few first LBA influences. It remains therefore doubtful if this level corresponds to a homogenous occupation layer combining these elements or rather to a fill consisting of mixed material belonging to the long time span between the end of level 7 and the beginning of level 5c3.

Level 5 dates to the LBA and Early Iron Age (EIA). Initially, level 5 was divided into three horizons. In 2006, new excavation allowed the chronology of level 5 to be reinterpreted. ${ }^{22}$ A general review of the level's stratigraphy and associated pottery was carried out in 2007. Levels 4, 5a and 5b and one dwelling structure were assigned to the Iron Age. The three LBA levels contained within level 5c were further subdivided (levels 5c1, 5c2 and $5 \mathrm{c} 3$ ) and correspond to three habitation levels (S2, S3 and S4). ${ }^{23}$ New radiocarbon dates are consistent with those obtained in 1993. They place level 5cl to between 1400 and 1000 BCE, ${ }^{24}$ what comprises the dates of the few Mycenaean sherds (LH IIIB to Submycenaean), 5c2 (floor level S3) to $1430-1225 \mathrm{BCE}^{25}$ and 5c3 to $1603-1322 \mathrm{BCE}^{26}$ The architectural remains are scanty in level 5 , but several structures as hearths, ovens and floors have been discovered. Hearths formed by a spread of sherds are of great interest, as first vases can be refitted and second they have in some instances been rebuilt over several levels at the same location. ${ }^{27}$

Level 4 is a turf sediment, and covers the last anthropic level 5a. It still includes a good amount of pottery originating from the underlying EIA levels. This level corresponds to Sovjan's abandonment due to a higher water level. Several potsherds suggest a date between

21 Ly-12099 and Ly-12100: Lera - Touchais (2004-5) p. 1123. The contexts of the two samples indicating a later date (Ly-7340 and Ly-7345, Lera - Prendi - Touchais (1996) p. 1006 and p. 1007 table 3.) have turned out to belong to level $5 c 3$ (Ly-7345) and the interface between levels $5 c 3$ and 6 (Ly-7340). There is therefore no C14 evidence for a LH I(-II) date as proposed previously for level 6.

22 Lera - Touchais (2007) p. 1051 fig. 1-2.

23 Lera - Touchais (2008) p. 877; Lera - Oberweiler - Touchais (2011) pp. 41-52.

24 Lera - Oberweiler - Touchais (2010) p. 50.

25 Lera - Touchais - Oberweiler (2009) p. 711.

26 Ly-7345: Lera - Prendi - Touchais (1996) p. 1006 and p. 1007 table 3. This sample has been interpreted as belonging to level 6 in previous literature on Sovjan but a re-examination of its context let to an attribution to level 5c3 (see above).

27 Lera - Touchais (2004-5) p. 1101-1102. 

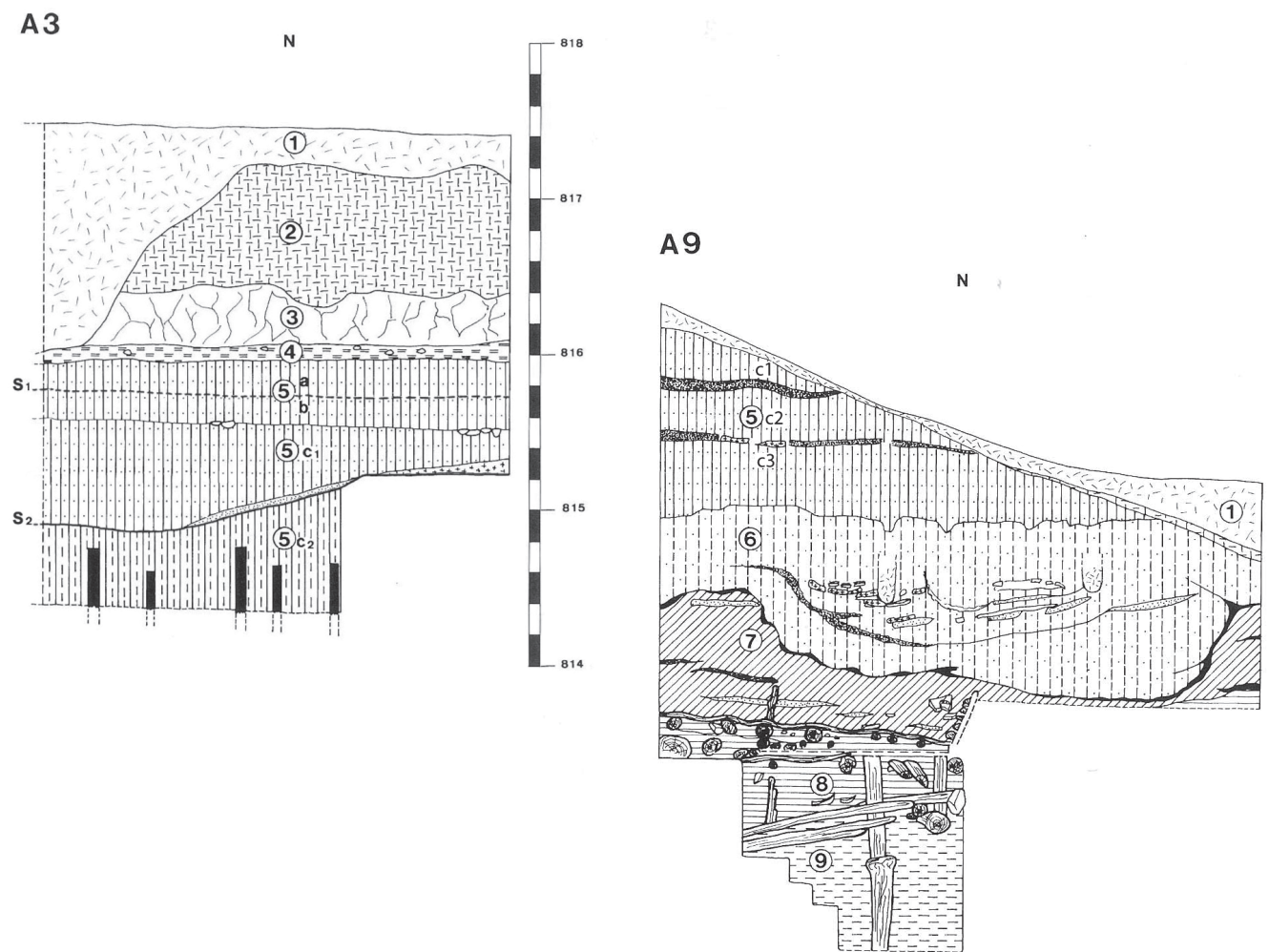

Fig. 1. "Section of Sovjan, trenches A3 and A9, North."

800 and $700 \mathrm{BCE}$ or the end of the EIA. Radiocarbon dates however place level 4 to a younger chronological horizon, between 527-214- CE and 50-180 CE, ${ }^{28}$ confirming that it represents the site's abandonment. The following level 3 consists of clay, accumulated on the bottom of the lake. ${ }^{29}$

The grey surface level (level 1) consists of backfill from the construction of the drainage canal and contains heterogeneous archaeological material. The two underlying levels (levels 2 and 3) are sterile alluvia composed of clayey-sandy soils.

\footnotetext{
28 Lera - Touchais (2008) p. 879.

29 Lera - Touchais (2008) p. 877.
} 


\section{Overview of Wares and Techniques}

While the Early Bronze Age levels 9, 8 and 7 are now fully published, ${ }^{30}$ the pottery from the Late Bronze Age and Early Iron Age layers is still under study. ${ }^{31}$ Therefore, the detailed codification used for the EBA will not be adapted here for the LBA and EIA phases. Since LBA and EIA pottery are quite different from the EBA assemblage, it seemed more useful to use a categorisation comparable with the reference publications from Central Macedonia (Kastanas and Agios Mamas) ${ }^{32}$ for these periods and than to continue the scheme developed for the EBA at Sovjan. This methodological choice, thus, reflects the relevance of the cultural changes observed in pottery production that occurred during the Late Bronze Age.

The pottery from the Bronze and Early Iron Age levels was manufactured entirely by hand, often using coiling. The only exceptions are a few imported wheelmade pots that appear in Sovjan starting from level $5 \mathrm{c} 1 .{ }^{33}$ Fabrication techniques observed with the naked eye seem fairly homogeneous. However, some technical features such as a clay pivot being used to attach the handle to the pot's wall are observed only on LBA pottery. Instead, EBA handles were attached to the body by pressing the lump of clay onto the surface of the vessel (Fig. 3). Other differences in technological features concern pyrotechnology. Pottery from EBA levels was fired in bonfires. The reductive atmosphere gives to pottery from levels 9, 8 and 7 the characteristic black-greyish surface and section colour. Starting from level 7, but more evidently in level 6 and then 5, pottery firing technique seems to have undergone some changes, evident in the surface and section colour, which are definitely changing towards brighter and reddish colours. ${ }^{34}$ Observations made with the naked eye need to be substantiated in the future with targeted analyses aiming a better understanding of the development of Sovjan's pottery firing technology.

Before level $5 \mathrm{cl}$ pottery is never painted but frequently decorated with impressions, usually sequences of impressed strokes, as well as plastic elements such as dots or cordons and occasionally incisions or grooves. Apart from burnishing, surfaces are seldom treated with other techniques (as in very rare cases the application of a slip). Generally, surfaces

30 Gori (2015a).

31 Lera - Touchais - Oberweiler (2012-3) p. 711-712.

32 Hochstetter (1984) and Horejs (2007).

33 The introduction of wheel-throwing in Albania was the topic of a paper presented by the authors at the 21st Annual Meeting of the EAA at Glasgow (2015).

34 Lera - Prendi - Touchais (1996) p. 1013 table 4. The general impression is certainly true, but it must be noted that there are joints between dark grey to black and reddish or brown sherds. 


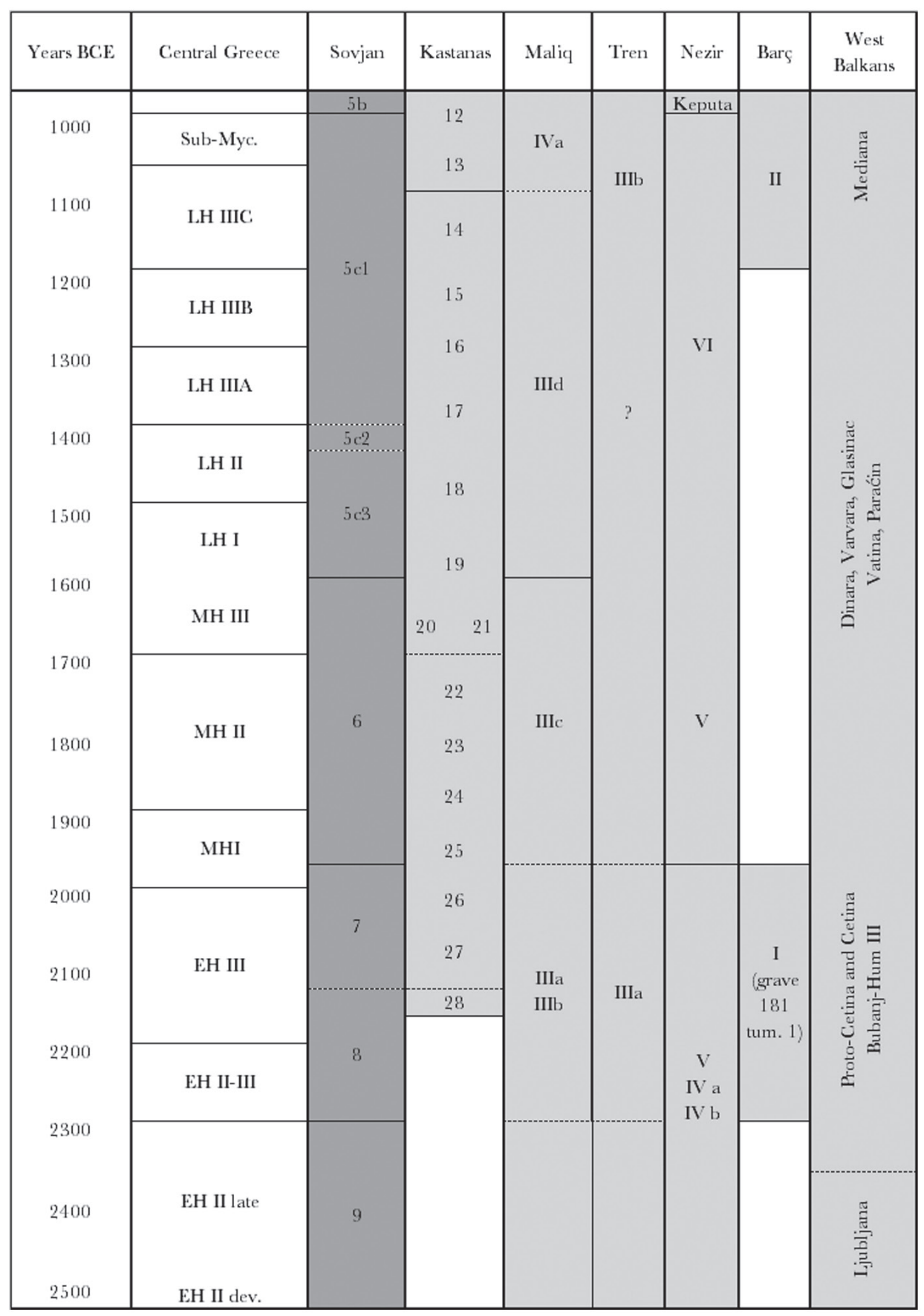

Fig. 2: Chronological Plate. 
were lightly polished, burnished or smoothed, presumably immediately after their shaping. Burnished surfaces bear patterns referable to directional tool use. This surface treatment is most frequently observed in EBA Sovjan. In levels 9, 8, 7 and 6, burnishing is the only way to roughly distinguish drinking and serving vessels of a higher quality.

The lack of fabric standardisation and the use of irregular tempers of the same geology make it impossible, especially for levels 9, 8, 7 and 6, to identify ware groups. For this reason Sovjan's EBA (and MBA) pottery is to be considered simply as coarse ware. Similar observations were made in respect to EBA pottery assemblages at Kastanas, where the differentiation into classes has proved ineffective. ${ }^{35}$ On the contrary, further south, for example at Pevkakia Magoula ${ }^{36}$ and Lerna ${ }^{37}$ the pottery assemblages can be classified into different groups according to fabric. This divergence highlights the existence of macroregional differences between northern and southern pottery traditions at the end of the EBA. Variations in quality can be observed only from level 5c3, when a new class of fine ware was introduced, marking what is the typical LBA assemblage. This development continues until the end of the LBA in level $5 \mathrm{c} 1$, whereas the quality decreases again in the EIA. A few new fabrics, however, can be discerned in levels $5 \mathrm{~b}$ and $5 \mathrm{a}$. Compared to the earlier phases, defining a small number of pottery classes for the LBA and EIA, on the basis of temper type, size and quantity, surface treatment, firing quality and colour (only for the fine wares) seemed to be useful. However, the large bulk of coarse and semi-coarse wares still remains hard to classify.

\section{Terminology for Shapes}

Inherent problems in the choice of the terminology used to describe the pottery are well-known. Not only does the definition of particular shapes differ significantly from language to language, but it also varies according to scientific tradition. In this study, the distinction between closed and open shapes for EBA assemblages is based on an index derived from the ratio between height and mouth diameter. When the ratio is less than $1: 1$, the shape is considered open, conversely, when it is more than 1:1 the shape is considered closed. Instead, in the LBA assemblage open vessels are defined as having a rim diameter of $66 \%$ or more of the maximum diameter, whereas closed shapes have a rim diameter that is less than two thirds of the maximum diameter. This classification reflects actual cultural tendencies observed in LBA Kastanas and Agios Mamas. ${ }^{38}$ On the contrary, the classification systems

\footnotetext{
35 Aslanis (1985) p. 84.

36 Christmann (1996) p. 40.

37 Rutter (1995) pp. 12-13.

38 Hochstetter (1984); Horejs (2007) pp. 89-ff.
} 
used for the later periods or for pottery assemblages of other regions, such as at Kastanas or Pevkakia Magoula, can't be applied on the EBA assemblage. If we consider the concept of type as reflecting the potter's mental models, the fact that we were not able to use the same system to classify the entire Sovjan assemblage from the Early Bronze Age to Iron Age, is a further indicator for cultural changes throughout time.

For the EBA pottery, bowls are large, open, and more or less articulated vessels with a height-to-mouth diameter ratio generally less than 1:1. Bowls can have vertical or horizontal handles and a continuous or an articulated profile. Cups and beakers essentially denote vessels that are smaller than bowls and have a height-to-mouth diameter ratio more than 1:1. Rim diameters range between roughly 6 and $15 \mathrm{~cm}$ and, and like bowls, their profiles can be continuous or articulated. In the typological classification employed for the EBA in Sovjan, cups are distinguished from beakers based on the presence (cups) or absence (beakers) of handles. In most cases, cups have one handle, however, types with two handles are also known. The term tankard describes - for the EBA pottery - narrow-mouthed drinking vessels whose rim diameter is always appreciably smaller than their maximum diameter. They can have either one or two vertical handles attached to a deep convex body profile. Tankards and bowls with two handles are commonly referred to in literature by their Greek name kantharos, a drinking vessel characterised by its high swung handles extending above the lip of the vessel. This shape in its many variations is characteristic of the LBA as well, where the term kantharos is also used to describe LBA fragmentary vessels with only one characteristic handle when the existence of a second cannot be ascertained. The open vessels of the LBA are subdivided into deep bowls (Schüsseln) and shallow bowls (Schalen), according to the German nomenclature used in Kastanas and Agios Mamas. Two additional size categories based on rim diameters are employed to make the classification more effective. The limit between the two is set at $18-22 \mathrm{~cm}$.

In Sovjan, jars are large closed vessels with or without a distinct neck, whose mouthto-height ratio is less than 1:1. Their body can be more or less articulated and they may have horizontal or vertical handles. In regard to LBA pottery, two terms are used: "amphora" for the narrow-necked jars regardless of the handles as they are rarely well-preserved enough, and simply "jar" for the wide-mouthed types. Jugs are rare and do not become a common shape before the end of the LBA.

Movable cooking stoves are earthenware objects used for food processing and are associated with the direct use of fire. Movable cooking stoves are known by their Greek name pyraunoi, a generic term for portable cooking equipment defined in scientific literature as "portable hearths with or without an embedded vessel". ${ }^{39}$ Apart from some ambiguous

39 Fischl - Kiss - KulCSÁR (1997) p. 126. 


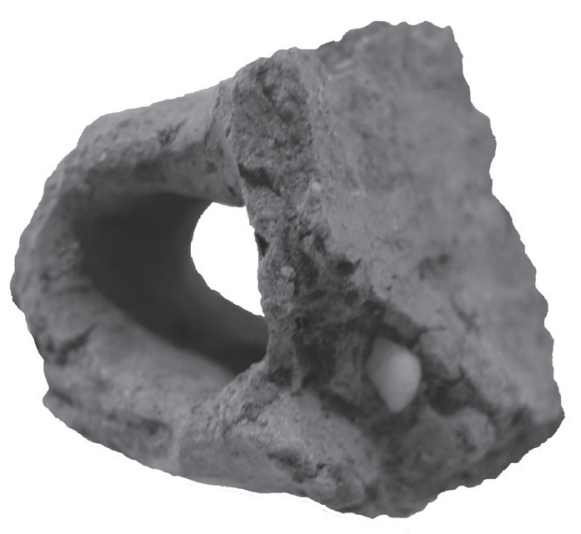

a.

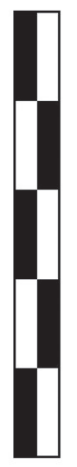

b.

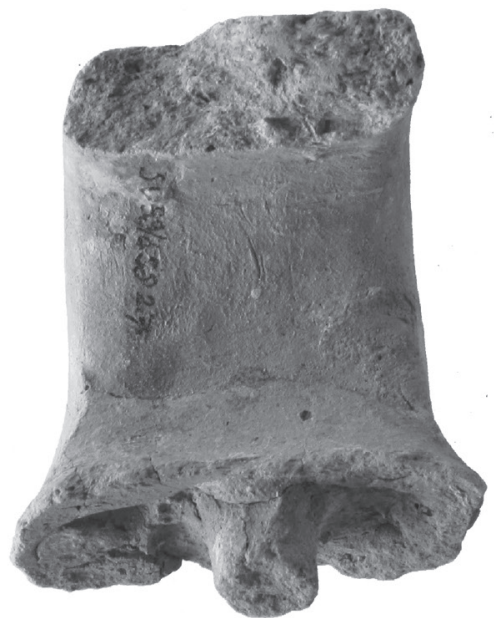

Fig.3. Different methods of handle attachments: a) handle glued on the vessel's surface (96/366.6, level 8) and b) handle with clay pivot for its attachment (99/458.27, level 6).

potsherds, there are no pyraunoi in EBA levels. In the LBA and EIA, the term pyraunos is widely used and restricted to cooking pots with an attached stand that is pierced by smoke holes and a firing opening. A rare type is a pyraunos with two massive feet.

The so-called smoking pots are known in scientific literature also as maquette de four or thurible depending on the functional interpretation. These vessels are peculiar to EBA Macedonia and seem to represent a fairly good chronological and cultural indicator of the very end of EBA. Finally, there are some strainers and miniature vessels to be found during the LBA.

\section{Description of the Pottery of the Different Layers Level 9 (Fig. 4)}

As only 60 out of the 84 potsherds recovered from level 9 were classified as well-defined shapes, for most of the bowls and jars isolating the most characteristic types is problematic. Unfortunately, because of the limited amount of pottery available for study, no distinctive typological elements distinguish clearly apart the assemblage of level 9 from those recovered from the levels 8 and 7. The only types exclusive to level 9 are kantharoi without distinct necks (type C.c.i.1 variety b, Fig. 4.1) ${ }^{40}$ and cups with S-profiles and everted rims (type B.a.ii.2 variety $a$, Fig. 4.2). Other typological trends are more difficult to pinpoint. Only a few different types of bowls with continuous profiles are present in level 9. Most of them are

40 Definitions of types are the ones used in Gori (2015a). 

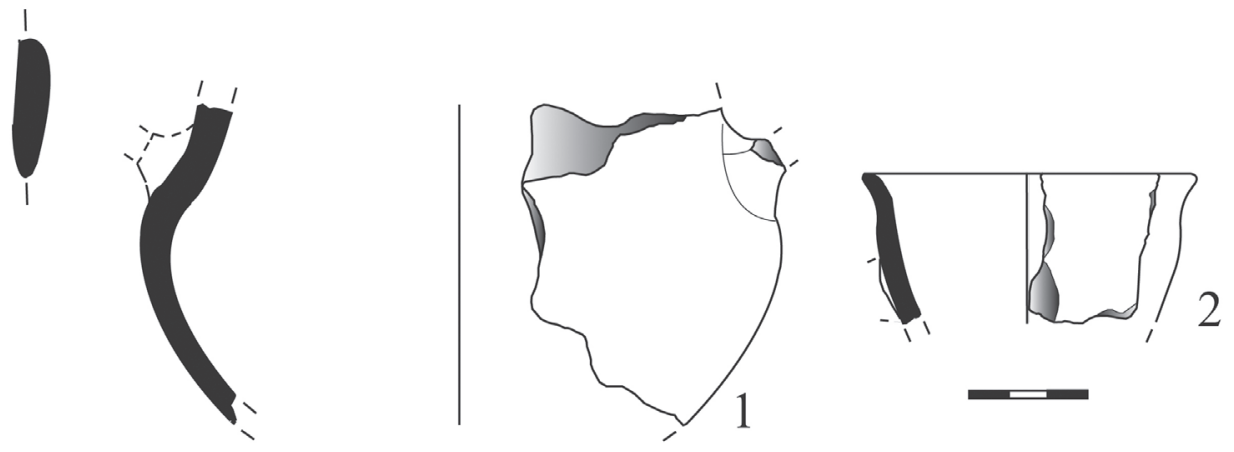

Fig.4. Pottery from level 9: 1 (01/626.4), 2 (01/626.22).

rather generic and quite common in the area. A strong typological continuity can clearly be seen with the bowls from level 8 and, to a lesser degree, level 7 . While the only radiocarbon date from level 9 is broadly consistent with the dates from Mandalo-phase III, Argissa Magoula and Sitagroi Vb, the pottery assemblages from these sites show close affinities with Sovjan levels 8 and 7, making it practically impossible to discern the exact chrono-cultural context of level 9 on comparative basis.

\section{Level 8 (Fig. 5)}

The pottery assemblage from level 8 has only few distinctive typological elements differentiating it from those of levels 9 and 7. Most of the pottery assigned to level 8 comes from the Maison du Canal. As was already observed for level 9, Sovjan bowls display minor typological changes throughout time, reflecting a pronounced formal conservatism. Not only do the simpler bowls, those with a continuous profile, seem to resist formal change over time, but also most of the bowls with articulated profiles seem to persist fairly unchanged through the different phases of Early and Middle Bronze Ages at Sovjan. This trend is even more evident in bowls whose maximum diameter is on the body. On the other hand, beaker and cup shapes changed quite rapidly from one phase to another and can be regarded as chronological indicators of level 8. Cups and beakers represent 10\% of the shapes recorded in this level. A fairly good number of types of cups and beakers are exclusive to level 8: cups with lens-shaped bodies and vertical strap handles on the body's point of maximum expansion (type B.b.1. Fig. 5.1), cups with continuous profiles and straight walls (unicum B.a.i.a.4, Fig. 5.2), cups with globular bodies and plain, everted rims (type B.b.6 variety $a$, Fig. 5.3), and beakers with continuous profiles and straight walls (type B.a.i.a.1, Fig. 5.4). The type B.a.i.a.1 includes $10 \%$ of all the cups and beakers recorded in level 8. In contrast to the bowls, $25 \%$ of all cup and beaker types recorded in Sovjan levels 9, 8 


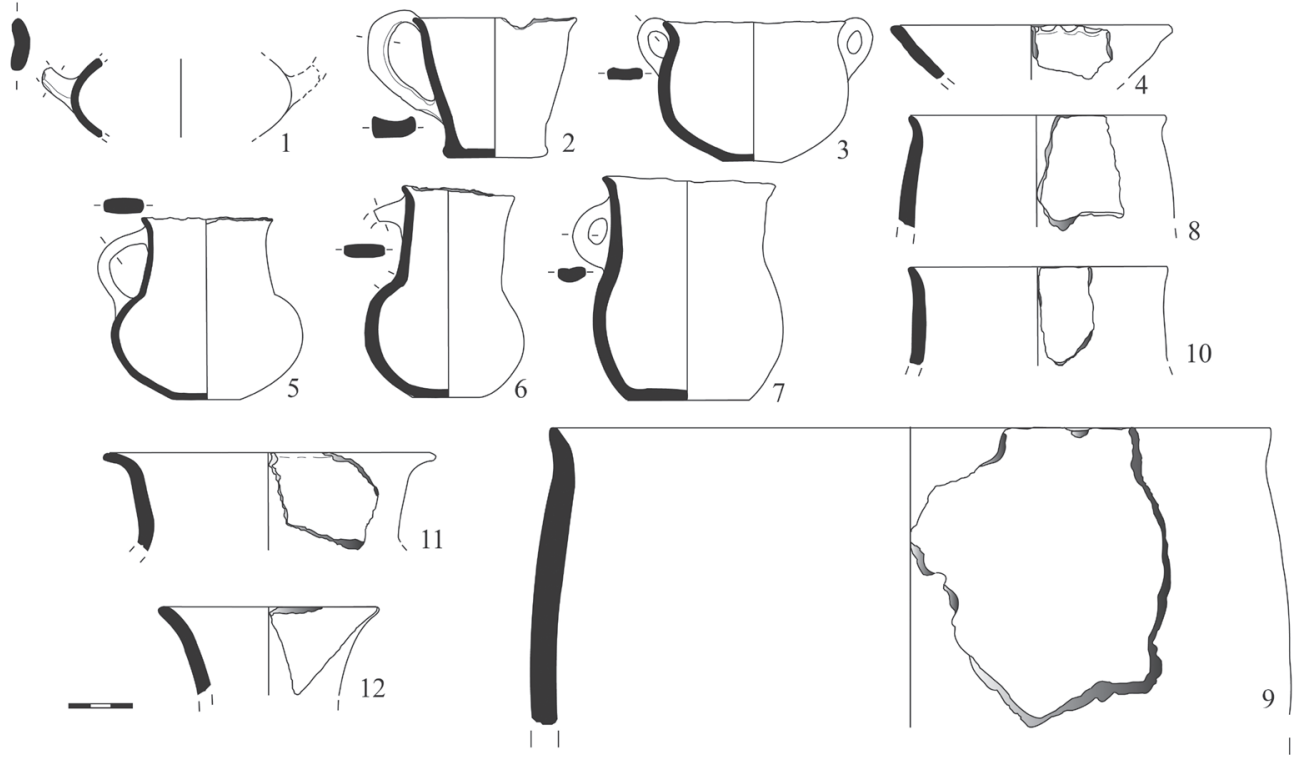

Fig. 5. Pottery from level 8: 1 (96/337.6), 2 (01/651.4), 3 (03/544.6), 4 (01/648.26), 5 (01/648.5), 6 (99/486.3), 7 (00/611.1), 8 (01/712.20), 9 (03/546.12 and 03/546.13), 10 (03/503.9), 11 (01/686.10 and 01/686.39), 12 (01/712.14). N. 6 comes actually from level 7 but it was chosen because it is the better preserved example.

and 7 appear exclusively in level 8. This rapid typological change, therefore, makes these types fairly reliable as chronological markers. Very few potsherds ( $5 \%)$ from level 8 belong to tankards. No tankard types were found exclusively in level 8. The only kantharos type characteristic of this level is the one with a nearly biconical body (C.a.3 variety $a$, Fig. 5.5). In general, pottery from level 8 compares to examples from Kastanas Schicht 27, Kritsanà Siedlung III and Sitagroi Vb. However, examples belonging to type B.b.6 can be compared, both in terms of body shape and handle position, with cups from the Belotić Bela Crkva group known from central Serbia, and with the Bass bowls made in fine grey burnished ware, which spread across central Greece and into the Peloponnese area during the Early Helladic III. ${ }^{41}$ Tankards with nearly biconical bodies (type C.a.3 variety a) are closely related to tankards type C.a.2 (variety a, Fig. 5.6) recorded both in levels 8 and 7. These types also connect Sovjan to both Belotić-Bela Crkva and the Aegean areas. ${ }^{42}$ Tankards C.a.2

\footnotetext{
41 Gori (2015b).

42 Gori (2015a).
} 
(variety $b$, Fig. 5.7) reveal similarities between level 8 and proto-Cetina assemblages. Jars are the best represented shape in level 8, comprising $40 \%$ of all the recorded types. With the exception of one example belonging to level 7, small jars with almost globular bodies

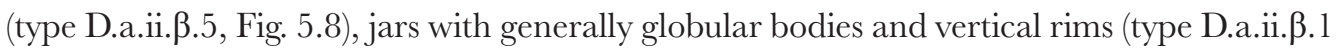
variety $a$, Fig. 5.9) and jars with generally globular bodies and everted rims (type D.a.ii. $\beta .2$ variety $a$, Fig. 5.9) were documented exclusively in level 8. Other jar types were documented exclusively in level 8: small jars with roughly cylindrical necks (type D.b.iv.2 variety c, Fig. 5.10), jars with long tapering necks and flaring rims (type D.b.iv.5, Fig. 5.11), small jars with elongated bodies (unicum D.b.iv.9), and small jars with narrow, flaring necks (type D.b.iv.10). Of the several jar types recorded exclusively in level 8, only type D.b.iv.5 and unicum D.b.iv.9 (Fig. 5.12) show typological parallels with examples from other assemblages as with the jars with cylindrical necks from Olympia, even if their high degree of fragmentation makes this parallel somewhat uncertain, with a jug from Agios Athanasios and, perhaps, with a jug from Toumba Episkopis. One smoking pot (type F.1) was recorded in level 8.

\section{Level 7 (Fig. 6)}

The number of bowls increases slightly from level 8 to level 7, where bowls with articulated profiles represent the overwhelming majority. Bowls with continuous profiles are less frequent in level 7 compared to level 8. In fact, their number decreases dramatically from $49 \%$ to $26 \%$ of the total of the bowls recorded in level 8 and level 7 , respectively. In level 7, bowls with articulated profiles are substantially more numerous than those with continuous profiles. Cap-shaped bowls (type A.a.ii.p.1 variety b, Fig. 6.1) are the only bowl type with a continuous profile present exclusively in level 7. Typological parallels for these bowls are known outside the Korça Basin, mostly in central Macedonia (Kastanas) and Thessaly (Argissa Magoula). At Sovjan, a single carinated bowl was recorded from level 7 (unicum A.b.vi.P.1, Fig. 6.2). This type becomes more common in later levels. The presence of carinated bowls in more recent contexts suggests carination to be a characteristic indicator of a chronological horizon successive to the Early Helladic III. Similar bowls are present in Sveta Nedela and in other Late Bronze Age sites, including Agios Mamas/Toumba Olynth. ${ }^{43}$ Furthermore, it is interesting to note that the overwhelming majority of articulated bowls from level 7 are deeper than in level 8. This typological characteristic may be chronologically indicative and might even reflect a transformation in dietary habits. In fact, progressive changes in the vegetal remains were observed throughout all levels, including 8 and 7 . In comparison to level 8, very few features were identified, the most relevant being the Maison

43 Sveta Nedela (Gori [2015a] p. 375) and Agios Mamas (Horejs [2007] pp. 98-99). 


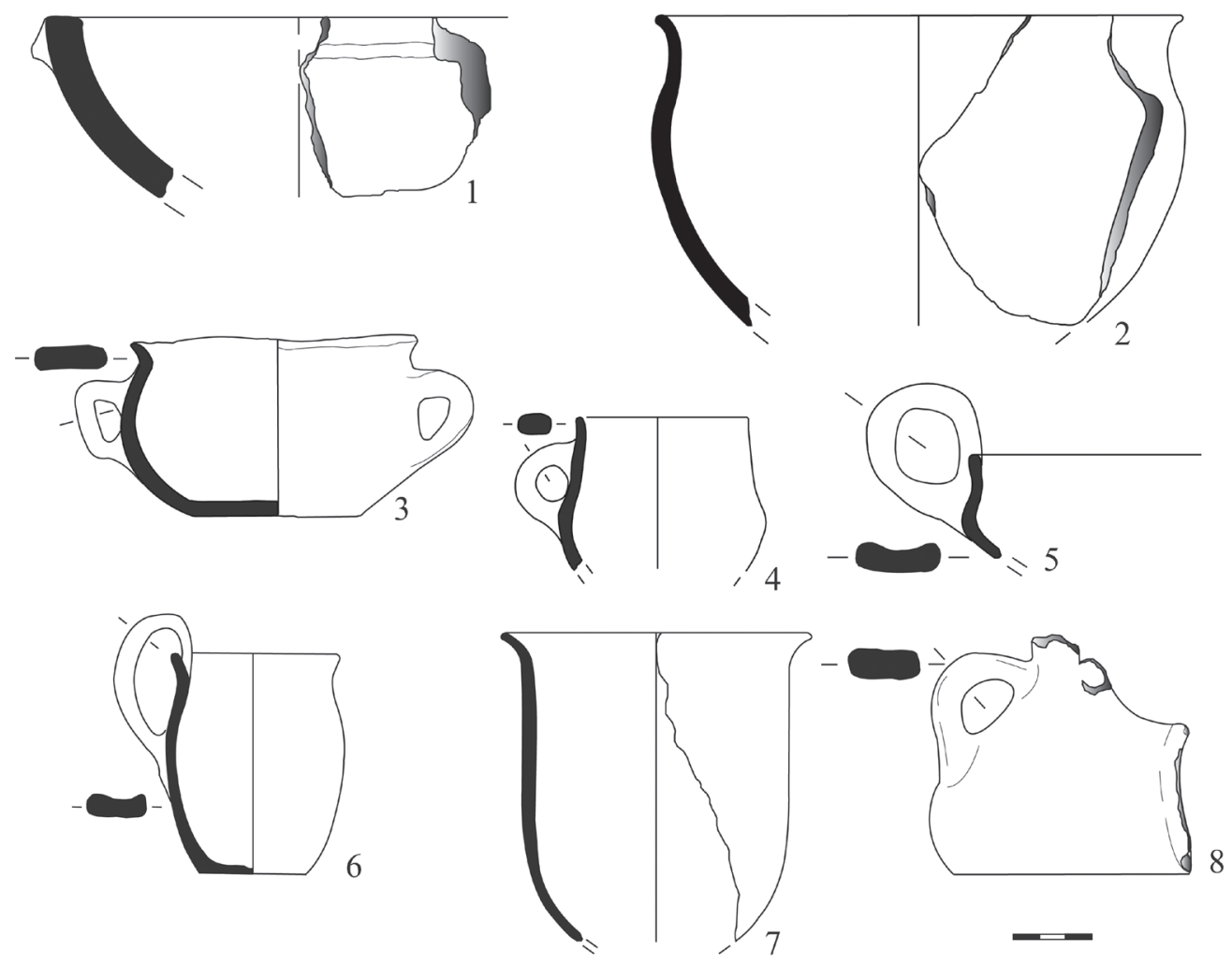

Fig. 6. Pottery from level 7: 1 (01/675.102), 2 (03/618.18), 3 (94/278.1), 4 (03/533.4), 5 (02/201.5), 6 (96/356.45), 7 (02/230.7 and 02/230.9), 8 (03/453.9).

Effondrée, a dwelling structure whose occupation surface was, unfortunately, only exposed in a very limited area. An entire tankard with a globular body (type C.a.2 variety a, Fig. 5.6, that was recorded in both levels 8 and 7) was found on the dwelling surface. Together with this tankard, a two-handled cup with a globular body (type B.b.6 variety $b$, Fig. 6.3) connects Sovjan to both the Belotić-Bela Crkva and the Aegean areas. In typological terms, cup type B.b.6 (variety b) compares well to the so-called Bass bowls made in fine grey-burnished ware, which spread across central Greece and into the Peloponnese area during the Early Helladic III, as well as to examples from Somogyvár-Vinkovci assemblages. Another cup type, B.b.2 (Fig. 6.4), also compares well to Somogyvár-Vinkovci types. Cups similar to unicum B.a.ii.3 (Fig. 6.5) and kantharoi recalling unicum G.a.1 (Fig. 6.6) are also present in the later levels of Sovjan (levels 6 and 5), while beakers similar to type G.b.1 (Fig. 6.7) were recovered from Sveta Nedela (type C.3). The fact that some of the types present exclusively in level 7 were also recorded in later levels at Sovjan (6 and 5) and at Sveta Nedela, supports their relevance 

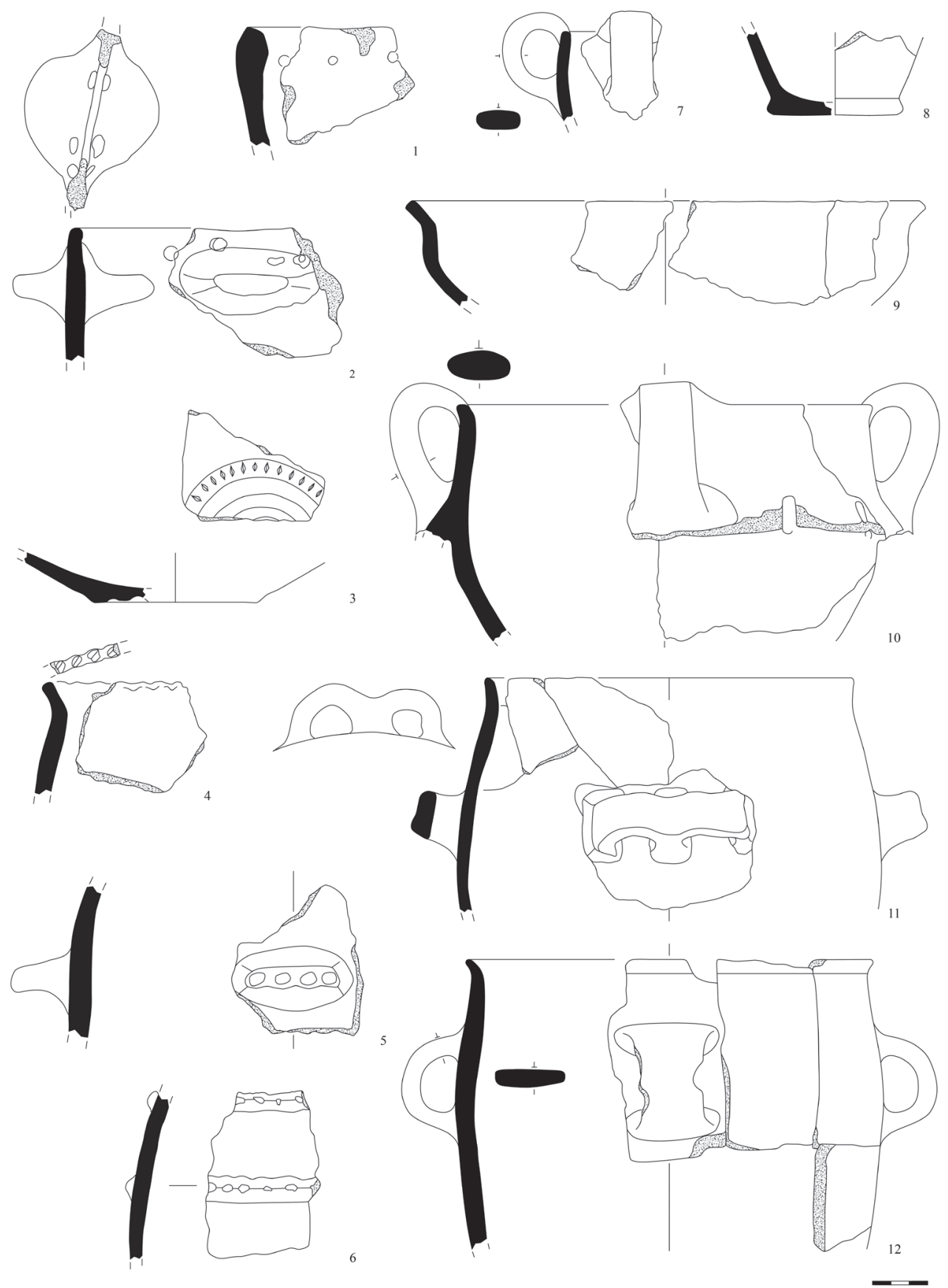

Fig. 7. Pottery from level 6: 1 (01/688.14), 2 (01/687.81), 3 (02/179.13), 4 (96/348.15), 5 (01/688.13), 6 (96/348.22), 7 (01/687.22), 8 (96/348.16), 9 (01/688.19), 10 (99/472.7), 11 (01/685.21), 12 (02/166.16). 
as chronological markers for the transition from the Early to the Middle Bronze Age. Three examples of smoking pots (type F.1, Fig. 6.8) were recovered from level 7, signifying an increase compared to level 8, where only one example was found. Comparable vessels from dated contexts show a chronological horizon coincident with the end of Early Helladic III, in some cases suggesting a chronological horizon of the first phase of the Middle Helladic. Level 7 has been radiocarbon-dated to between 2300 to 1950 BCE, making it broadly contemporaneous with Archontiko phase B, which is composed of several building phases (II, III, IV) and similarly dated to between 2300 and 1900 BCE. Unfortunately, there are few direct typological parallels between Sovjan levels 9, 8 and 7 and Archontiko, but this may be due to the fact that the pottery from Archontiko is yet to be fully published. Overall, the available radiocarbon dates and pottery assemblages are consistent with level 7 dating to the very end of the Early Bronze Age (Early Helladic III) and the beginning of the Middle Bronze Age (Middle Helladic I).

\section{Level 6 (Fig. 7)}

The character of the level 6 pottery assemblage is more difficult to define. Stratigraphically it is situated between levels 7 and 5c3 and consequently the pottery shapes still adhere mainly to the tradition of level 7 but show equally LBA elements. A marked technological development, indicated by the decrease of fabrics fired in reducing condition and the introduction of plugged-in handles, and the first appearance, in admittedly rare instances, of typical LBA phenomena such as a first pyraunos in a secure context (Fig. 7.10; floor S4) ${ }^{44}$ connect level 6 to the following LBA levels. Nonetheless, most shapes reflect the EBA typology and a pronounced change in taxonomy will become recognisable only in levels $5 \mathrm{c} 3$ to $5 \mathrm{c} 2$. For example, the large coarse ware basins with in-turned rims and perforations below the lip (Fig. 7.1) as well as the basins with lug handles in- and outside (Fig. 7.2) are typical EBA and MBA shapes ${ }^{45}$ that were still being produced in level 6 but not any more in the $5 \mathrm{c}$ levels. However, some large irregular basins without perforations are known from level 5c3. As in the EBA, strap handles are round (Fig. 7.12) and when placed at the rim do hardly

44 In Kastanas, pyraunoi were already introduced in layer 19 (MH III to LH I) and stayed in use throughout the LBA (Hochstetter 1984 [1984] p. 157). A pyraunos from Toroni has been published as MBA (Morris [2011] p. 438 fig. 7). It must be noted that the kantharoi in Lera - Touchais (20045) p. 1131 fig. 47 are more recent then level 6 as stated in the legend. In fact, this level in trench A8 belongs to $5 \mathrm{c}$ and not 6 .

45 Sovjan levels 8 and 7. Maliq IIIa: Prendi (1982) p. 206 fig. 2 and Prendi - Bunguri (2008) pl. 22. Kastanas 26-24 (Pfannen): Aslanis (1985) p. 173 and p. 173 fig. 92. 

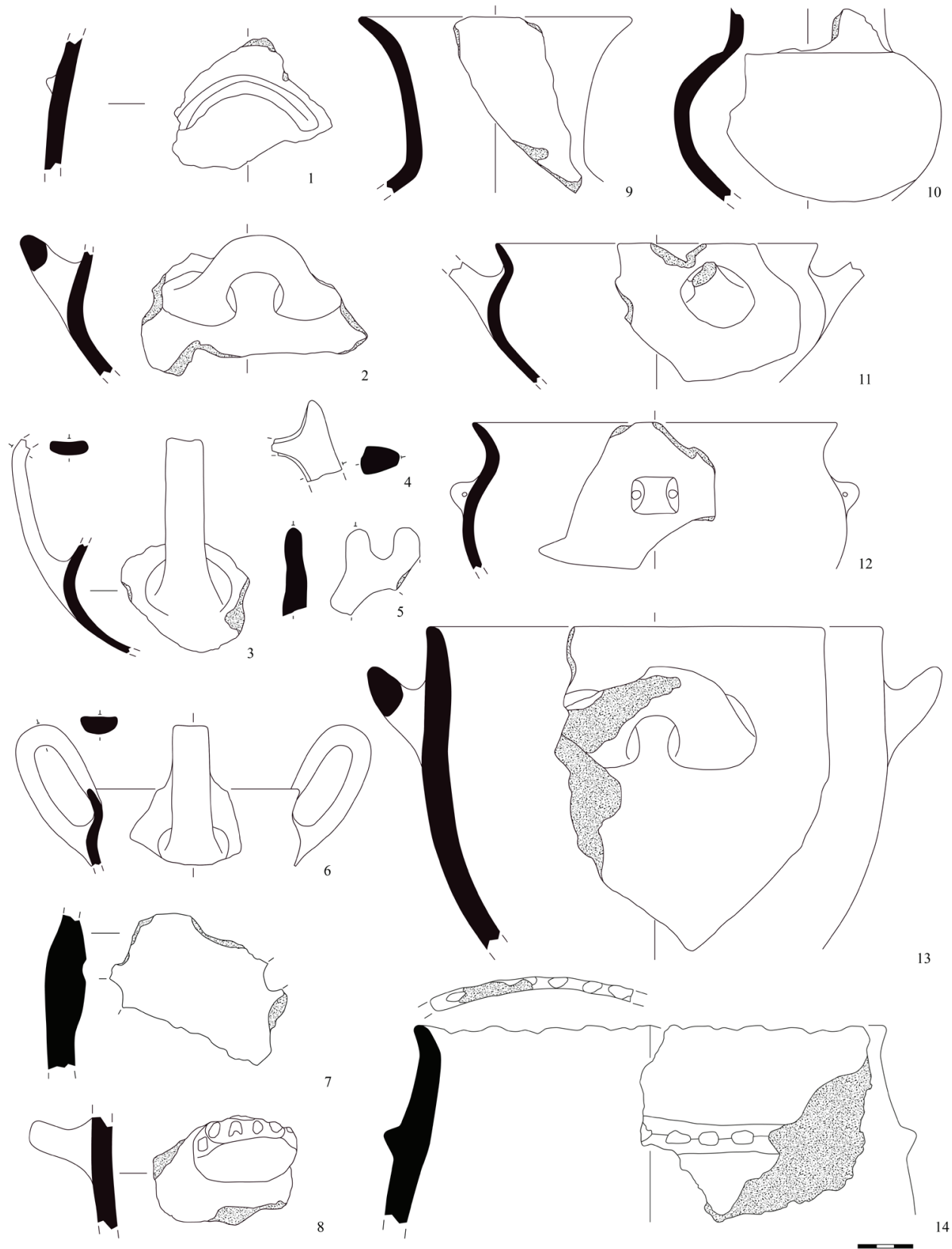

Fig.8. Pottery from level 5c3: 1 (96/344.19), 2 (01/659.48), 3 (01/659.41), 4 (99/420.7), 5 (94/247.13), 6 (96/344.9), 7 (01/667.19), 8 (01/662.38), 9 (01/659.50), 10 (01/662.32), 11 (99/421.4), 12 (96/344.21), 13 (99/414.16), 14 (01/659.1). 
jut out above the lip (Fig. 7.7). Noteworthy is a complete kantharos in a grey fabric with high handles and S-profile, found at the bottom of level $6 .{ }^{46}$ Such kantharoi existed in Maliq IIIc alongside the round vertical belly handles ${ }^{47}$ and are normally considered as typical of the MBA. A few horizontally placed strap handles on jars ${ }^{48}$, which can even be double (Fig. 7.11), are reminiscent of older phases.

Even if a new method for attaching the handle to the pot by pushing it through the vessel's body is introduced, it doesn't replace the traditional manner of pressing handles simply onto the body's surface. This new practice will remain in use throughout the LBA phases. Vessels' profiles are normally rounded and less articulated than in the following horizons (almost angular profiles as in Fig. 7.9 are much less frequent than round ones), and the bases are mostly flat (Fig. 7.8), also differing from the following phases. The table ware consists mainly of bowls, cups and a few kantharoi, either semi-spherical or with S-profiles and out-turned lips (often with the maximum diameter at the rim). The jars have usually almost straight or slightly rounded walls, out-turned lips and lugs or handles on the upper body. The fabric is always coarse or semi-coarse (except for a handful of small and thin-walled vessels) and the only means by which table ware can be distinguished is by its burnished surface. Decoration is restricted to plain and impressed horizontal plastic bands (Fig. 7.6) and rows of simple impressions on the upper bodies of the pots. Impressions on lug handles (Fig. 7.5) are an innovation of level $6^{49}$ and rims are more often impressed in levels 6 and $5 \mathrm{c} 3$ than in later phases (Fig. 7.4). A double ring base with impressions is rare (Fig. 7.3).

These characteristics testify to the strong connection between level 7 and 6 . In terms of pottery technology there are some innovations in level 6 , but the major changes will appear in level 5c3. The presence of first LBA elements makes at least a partial attribution to this period plausible. However level 6 must cover part of the preceding MBA as well, especially if the early C14 date for the beginning of level 5c3 turns out to be correct. Parallels with Maliq IIIc further strengthen this hypothesis.

\section{Level 5c3 (Fig. 8)}

LBA culture in terms of pottery styles definitely begins in level 5c3. The major novelties are the fine and semifine wares, traditionally in grey but also in orange-brown fabric. Especially the orange ware develops into a very fine fabric with almost no macroscopically

46 Lera - Touchais (2000) p. 636 and p. 637 fig. 10.

47 Prendi (1982) p. 211 fig. 5.

48 Cf. Maliq IIIa: Prendi - Bunguri (2008) pl. 14.1-2.

49 In Kastanas, this occurs already in level 26, that is earlier than Sovjan level 6. Aslanis (1985) pl. 8.6. 
visible inclusions, and it is used for thin walled table ware. Not surprisingly, the main shapes in these new fabrics are typical LBA types, such as the kantharoi with high handles or S-shaped bowls with horizontal handles. A finer fabric with few large inclusions (mainly quartz) is now used for some larger shapes as well, alongside the traditional coarse wares, a tendency that becomes even more marked in level 5c2. Firing technology in level 5c3 appears more sophisticated and oxidising conditions are generally preferred.

Most typical for this level is the kantharos with two handles rising high above the rim, which becomes more frequently attested. Differently from level $5 \mathrm{c} 2$, however, the kantharos handles are simpler, without protrusions or grooves on their top (Fig. 8.3 and 6). Innovative are also the horizontal handles on shallow S-shaped bowls, either round (Fig. 8.2) or of wishbone type (Fig. 8.4 and 5, probably also 11). The latter seems to be most frequent in level 5c3 but occurs in later levels as well. The appearance of such handles in Maliq IIIb and IIIc, according to F. Prendi, is problematic in comparison to Sovjan, where they are clearly a LBA feature. ${ }^{50}$ The wishbone handle bowls of hemispherical type and those with in-turned rims, which are characteristic for Central Macedonia, ${ }^{51}$ however, do not appear in Sovjan before the EIA. The S-shaped type with everted rim, on the other hand, is attested during the MBA in Central Greece already, ${ }^{52}$ the region whence according to B. Horejs ${ }^{53}$ the inspiration for the kantharoi originates. And it might already have appeared in Central Macedonia as early as in MBA. ${ }^{54}$ There is a large variety of handle types, both triangular and trapezoidal, but a preference for horned ones is evinced. ${ }^{55}$ Equally typical for level 5c3 are bowls with small horizontally pierced lug handles (Fig. 8.12). Such miniature handles were found in Cetush IV together with trapezoidal wishbone handles, alongside more developed kantharos handles that do not appear before Sovjan $5 \mathrm{c} 2 .^{56}$

Coarse ware jars are normally quite deep and have clearly out-turned rims. Deep large bowls might also have almost vertical rims (Fig. 8.13). In coarse ware, there are horizontal and vertical handles along with large lug handles. The number of flat bases decreased markedly in comparison to level 6.

Pyraunoi (Fig. 8.7) now constitute a frequent shape in the repertoire but are by far not yet as ubiquitous as in the subsequent levels $5 \mathrm{c} 2$ and $5 \mathrm{c} 1$. Narrow necked amphorae

\footnotetext{
$50 \quad$ Prendi (1982) p. 209.

51 Horejs (2007) pp. 103-108.

52 E.g. in Lianokladi and Ag. Paraskevi in the Spercheios valley (personal study by T. Krapf).

53 Horejs (2007) p. 126.

54 Heurtley (1939) p. 210 fig. 76 (Molyvopyrgos).

55 Krapf (2014a) p. 248 fig. 6.

56 Bunguri (2010) pl. LXXXIX-XCIII.
} 
complete the LBA assemblage (Fig. 8.9). High necks can equally occur on smaller closed shapes (Fig. 8.10). Pottery decoration is still restricted to impressions on the rim (Fig. 8.14), few crescent-shaped applications (Fig. 8.1) and finger impressed horizontal bands and lug handles (Fig. 8.8). Miniature versions of certain shapes are also produced.

\section{Level 5c2 (Fig. 9)}

In level 5c2 the pottery reached a mature LBA typology. The kantharoi have handles with protrusions and grooves on their top (Fig. 9.1, 2 and 10), as is typical for the wider region in the Southern Balkans. But it might actually be earlier attested in the Korçë basin as in Central Macedonia. Very frequently, they have a simple vertical upper extension, which in some cases is turned inwards. There are several varieties of pinched upper endings and grooves. Most characteristic is the appearance of one or three perforations or impressions on their upper attachments (Fig. 9.1 and 10). While single perforations and impressions occur in Central Macedonia and along the Vardar valley on matt painted kantharoi, triple perforations/impressions on plain kantharoi are a distinct feature of the wider region around the Korça plain and the Ohrid Lake. ${ }^{57}$ The kantharoi are either S-shaped or carinated with a concave shoulder. Bowls can similarly have this carinated shape, sometimes with small buttons placed on the carination (Fig. 9.12). Large deep bowls often have an unpronounced, gentle S-shaped profile (Fig. 9.11). They have several types of rather heavy horizontal handles on the shoulder. Less frequently horizontal handles can be placed on the rim (Fig. 9.13). Some bowls still have vertical belly handles as in level 6 and earlier. Wishbone handles are also present (Fig. 9.5).

Incised decoration is now introduced in the form of simple motifs, such as wavy lines and zigzags, often flanked by horizontal lines and triangles (Fig. 9.7-8). This development occurs relatively late compared to the appearance of incisions with typical LBA motifs in Kastanas already in level 19 (ca. $1600 \mathrm{BCE})^{58}$, but can be paralleled with an increase of this decoration type in level $17^{59}$. The incisions in Sovjan are never incrusted, except for one example in level 5cl (see below). Wavy rims - mostly for wide mouthed jars but also for some smaller shapes-, horizontal finger impressed and plain raised bands as well as simple plastic applications complete the range of level $5 \mathrm{c} 2$ decorative methods.

As noted for level 5c3, large storage jars are now produced in a quite fine fabric with large quartz inclusions and are much better fired than the usual coarse ware.

Pyraunoi (Fig. 9.14) are now present in large numbers and form, alongside jars and large

\footnotetext{
$57 \quad$ KRAPF (2015b) pp. 590-594.

58 Hochstetter (1984) pl. 1.

59 Hochstetter (1984) p. 204.
} 

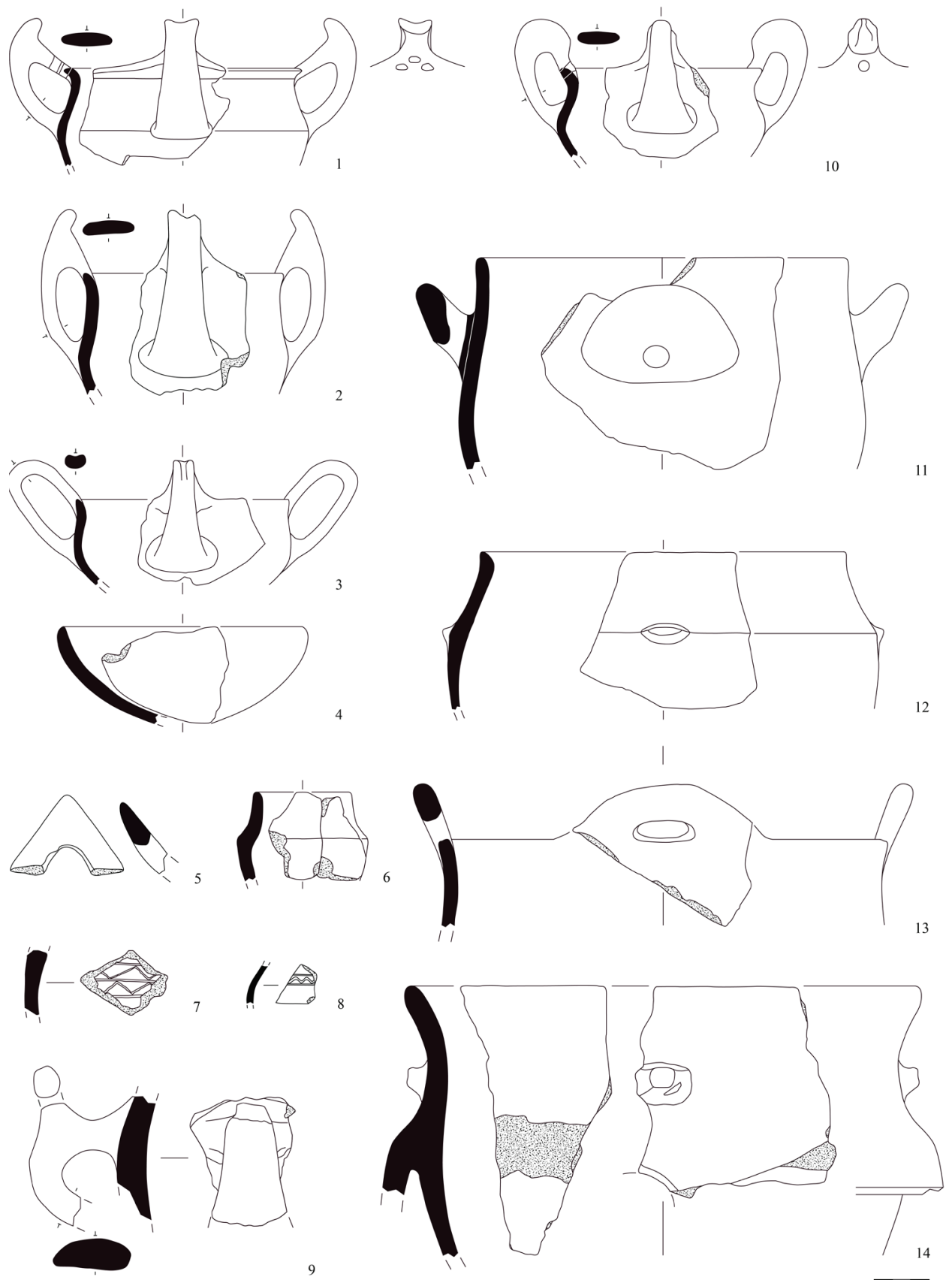

Fig. 9. Pottery from level 5c2: 1 (01/647.24), 2 (01/647.23), 3 (99/412.4), 4 (06/407.51), 5 (01/655.26), 6 (94/230.22), 7 (03/410.28), 8 (03/472.10), 9 (94/215.2), 10 (03/465.21), 11 (01/647.25), 12 (06/428.21), 13 (99/410.6), 14 (01/655.18). 
bowls, the standard cooking equipment. Their introduction indicates a certain change in cooking habits and an adaptation to a general trend of the south-western Balkans. ${ }^{60}$ Fragments and complete vessels have been published only from a few Albanian sites, including tumuli, but they must have had a very large distribution. ${ }^{61}$ Due to their fragmentary state a detailed typology for the Sovjan examples is impossible, however the pyraunoi and their decoration look in general much less varied compared to Central Macedonia or Bulgaria ${ }^{62}$. They all have a high attachment of the stand and a vertical upper part with a slightly out-turned lip. At the height of the attachment, they have vertical or horizontal handles and or even lug handles. The dimensions of the pyraunoi vary considerably, with the diameter fluctuating from less than $25 \mathrm{~cm}$ to over $45 \mathrm{~cm} .{ }^{63}$ The two-legged pyraunoi, however, as found in the tumulus of Kuç i Zi, ${ }^{64}$ seem to be an EIA variation (see below). ${ }^{65}$

\section{Level 5c1 (Fig. 10 and 11)}

With over 12'000 fragments, including a good number of complete profiles, level $5 \mathrm{cl}$ is by far the best defined of the LBA levels and represents well the local ceramic tradition of the Korça plain. It is, however, not always certain, whether the shapes of level 5c1 do not occur in other, less well-represented levels with smaller and/or worse preserved assemblages. C14 dates prove the considerable chronological horizon of this level (1400 to $1000 \mathrm{BCE}$ ), which is also corroborated by the Mycenaean imports dating from LH IIIB to Submycenaean (Fig. 10.4; kylix). The appearance of such imports in a settlement context is of outstanding importance, as most of the so far known Mycenaean ceramics found in Albania originate from graves. ${ }^{66}$ However, accounting for less than $0.1 \%$ of the ceramic assemblage of level $5 \mathrm{cl}$, their importance should not be overestimated. The unique incrusted sherd from Sovjan must also be classified as an import, since this type of pottery normally doesn't appear West of Central Macedonia. ${ }^{67}$

$60 \quad$ Horejs (2007) p. 152 fig. 97.

61 Kuç i Zi: Andrea (1985) pl. XXIII v.5/a no. 1; Maliq: Andrea (2009) p. 44 pl. III.7. Prodan: Aliu (1984) p. 60 pl. VI v.55 no. 54. Possibly even at Lofkënd: PApadopoulos - Morris - Bejko Schepartz (2014) p. 239. Fragments were also found during the survey of the Korçë plain by the French Albanian archaeological mission (PALM).

62 Bulgaria (2011).

63 Krapf (2015b) pp. 586-589.

64 Andrea (1985) pl. XXIII v.7 no. 2.; pl. XXIX v.43 no. 1

65 Bräuning - Kilian-Dirlmeier (2013) pp. 21-23.

66 BoDinAKU (1995).

${ }_{67}$ Horejs (2007) pp. 74-80. 

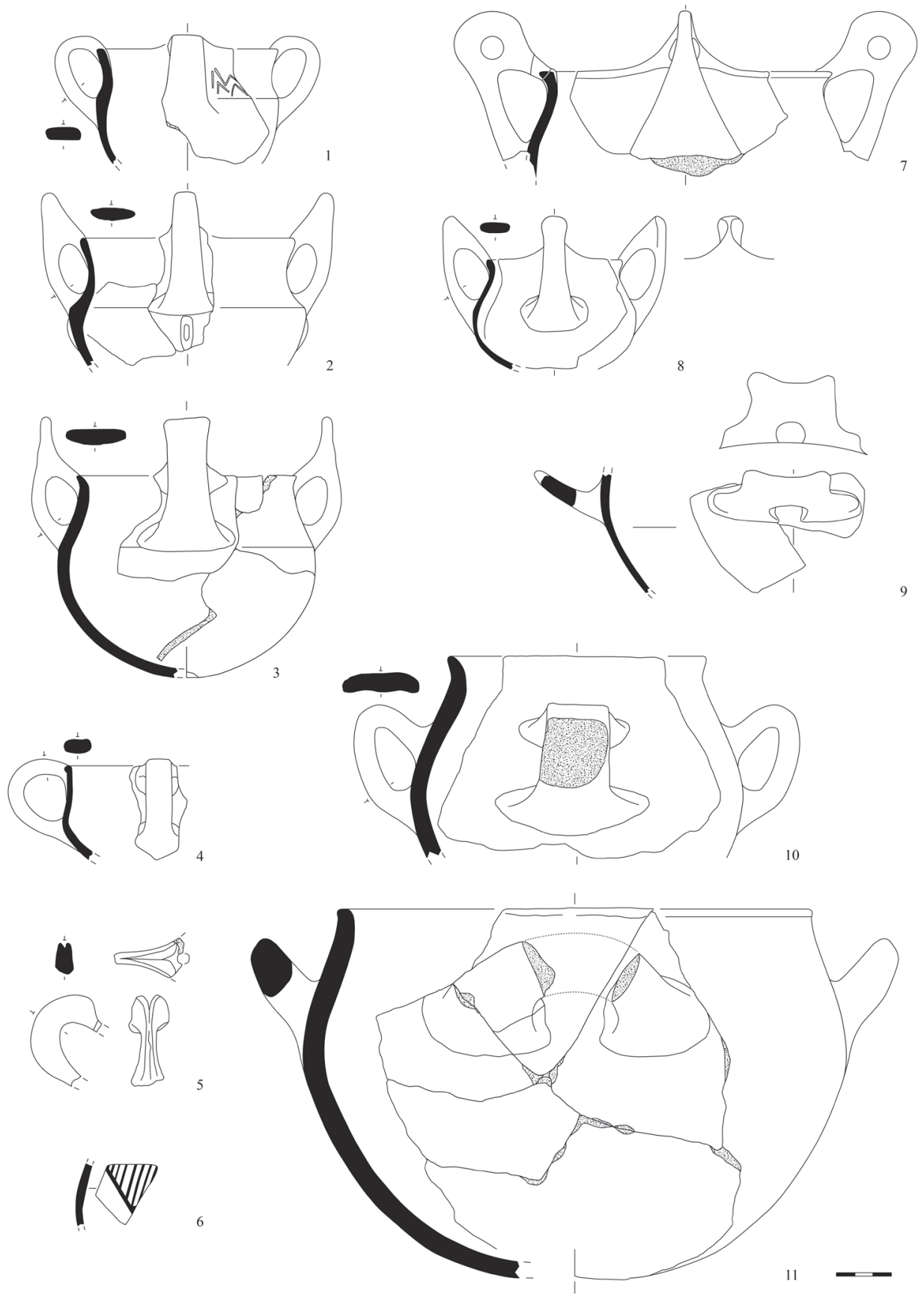

Fig. 10. Pottery from level 5c1: 1 (99/473.8), 2 (94/276.52), 3 (94/276.61), 4 (06/402.21), 5 (96/354.11), 6 (06/342.7), 7 (96/376.2), 8 (94/276.18), 9 (96/336.29), 10 (94/271.22), 11 (94/267.7). 
Contemporarily the first few matt painted fragments appear in well stratified units of level 5cl (Fig. 10.6). ${ }^{68}$ They are decorated with motifs already known from the incised pottery that persists into the EIA. It should therefore be argued, that matt painted pottery appeared in SE Albania already during the LBA, but became popular only during the EIA. Some sherds also bear pointillé decoration. ${ }^{69}$ Fine incisions instead of impressions can appear on rims, but the traditional finger impressions continue (Fig. 11.2 and 4)

The kantharoi (Fig. 10.1-3, 5 and 7-8) are mostly carinated or have S-profiles, but can also be of a hemispherical type with continuous profile. Miniature versions (diam. $5 \mathrm{~cm}$ ) as well as large examples (diam. over $20 \mathrm{~cm}$ ) indicate the popularity of this shape and its adaptation to serve different functions. There is even a pyraunos with a high vertical handle placed on the rim. ${ }^{70}$ The most important innovation concerning the handles is the appearance of double pierced handles of different types (bifora in Albanian) ${ }^{71}$ which, however, never occurred in larger numbers (Fig. 10.7).

Wishbone handles, placed on the bowls' shoulders are still present alongside other types of horizontal handles (Fig. 10.9). Deep spherical bowls (Fig. 10.10-11) were produced in semifine to coarse fabric and were consequently used for different tasks, including cooking alongside the pyraunoi (Fig. 11.8). Their rim is most often only slightly out-turned or completely vertical with a flattened lip. They have horizontal handles and sometimes crescent-shaped applications on their upper body. Wide mouthed jars at this level often have unpronounced profiles, with almost vertical rims. The narrow necked jars (Fig. 11.3 and 6-7), however, show significant variation, from cylindrical and concave necks to funnel shaped necks and short everted rims. Some have a pear shaped body (Fig. 11.1). As already in level 5c2 (Fig. 9.9), their vertical handles (Fig. 11.9) follow the typology of the kantharos handles: they are turned upwards or have an extension and they can even have a single impression on their upper attachment. This must constitute a local feature as such belly handles are not attested in Kastanas ${ }^{72}$ but occur for instance in LBA to EIA layers at the

68 KRAPF (2014b) p. 590 fig. 4. There is also one fragment in level 6, but this must be interpreted with caution, although this type of decoration was already widely used at the beginning of the LBA in Central Macedonia. In levels $5 c 3$ to $5 c 2$ are no attestations of matt painted pottery.

69 Lera - Oberweiler - Touchais (2010) p. 47 fig. 16.

70 Lera - Touchais - Oberweiler (2012-3) p. 712 fig. 36.

${ }^{71}$ Aliu (2004) pp. 80-81 and pl. XXVI no. 288-290.

72 Krapf (2014b) p. 594 and p. 593 fig. 7. 

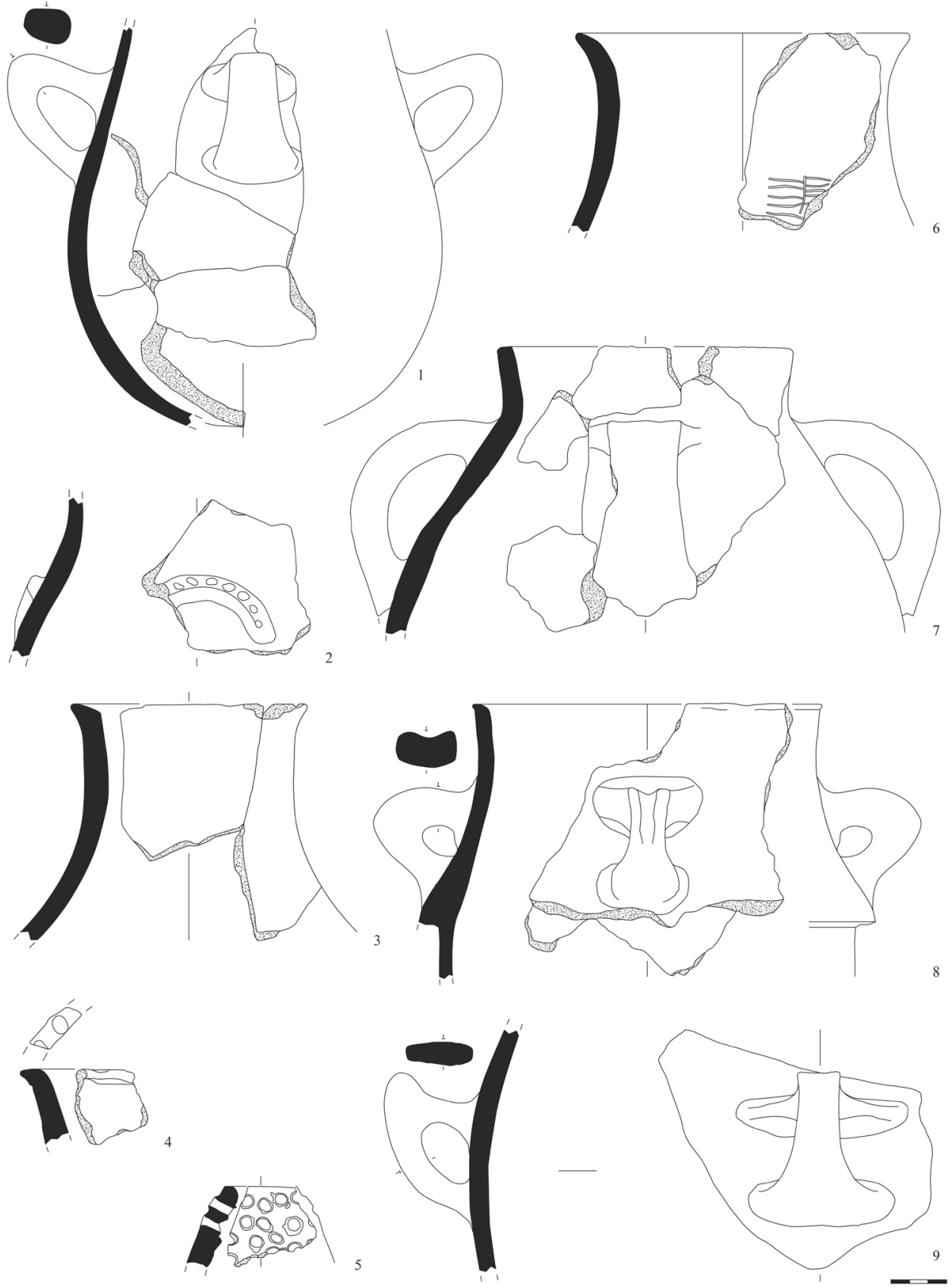

Fig. 11. Pottery from level 5c1: 1 (06/427.12), 2 (06/402.7), 3 (94/241.20), 4 (06/392.18), 5 (94/271.9), 6 (96/346.37), 7 (94/241.147), 8 (96/369.8), 9 (94/234.27). 
nearby sites of Tren ${ }^{73}$, Plocha Michov Grad at lake Ohrid, or Sveta Nedela ${ }^{74}$ at the Great Prespa Lake. Less frequently, such handles also appear on deep bowls and cups. A few sherds indicate the presence of strainers (Fig. 11.5) of open and closed types.

The top of level $5 \mathrm{cl}$ is marked by the appearance of EIA elements, such as channelled ware, ${ }^{75}$ bowls with in-turned rims, and finger impressed bands that are no longer just horizontal. This transitional period corresponds to the layers 13 and 12 of Kastanas. LH IIIC to Submycenaean potsherds further suggest a late date for the end of level $5 \mathrm{c} 1{ }^{76}$ While Maliq IIId corresponds to level $5 \mathrm{c} 1$, the transitional phase (according to Zh. Andrea) ${ }^{77}$ Maliq IVa has a considerable depth of 0.4 to $0.7 \mathrm{~m}$ and covers not only this thin transitional layer of Sovjan, but also large parts of level $5 b$.

\section{Levels 5 b and 5 a (Fig. 12 and 13)}

In general, a continuity can be observed in the ceramic tradition from the LBA to the EIA, especially when the transitional phase at the summit of level $5 \mathrm{c} 1$ is taken into account. But as the LBA, the EIA has its distinct markers that allow a secure attribution of assemblages to this period. The two EIA levels $5 \mathrm{~b}$ and $5 \mathrm{a}$ are treated here together, as their study is still in progress. These phases are best represented in the finds from the 1990 and 1991 excavation campaigns conducted under the direction of P. Lera (trenches A3-6, Fig. 13).

The most typical feature is the matt painted pottery, which becomes now popular and develops its typical style. In Maliq, the layers with matt painted pottery have correctly been re-dated by Zh. Andrea to the LBA-EIA transition and the EIA. ${ }^{78}$ The introduction of this decoration style is considerably late in comparison to Central and even Upper Macedonia, a fact that might surprise when one considers other features of foreign inspiration, already adapted during the LBA, such as the pyraunoi, and the Mycenaean imports, which most probably came from this direction. The same accounts for Epirus, which shares many traits with the SE Albanian EIA tumuli. Characteristic shapes of matt painted pottery in Sovjan are bowls with a marked out-turned rim and a clear cut edge inside at the junction of rim and shoulder and a spherical body (Fig. 12.1, 11), kantharoi, horizontal handled bowls (Fig. 12.10), jugs (Fig. 13.2) and amphorae (Fig. 13.1). The main motifs consist of pendant

\footnotetext{
73 Korkuti (1971) pl. VIII.25-26.

74 Gori (2015a) pl. CVIII.

75 Lera - Oberweiler - Touchais (2010) p. 47 fig. 16.

76 Lera - Oberweiler - Touchais (2010) p. 49.

77 Andrea (2009) pp. 7-24.

78 Andrea (2009).
} 


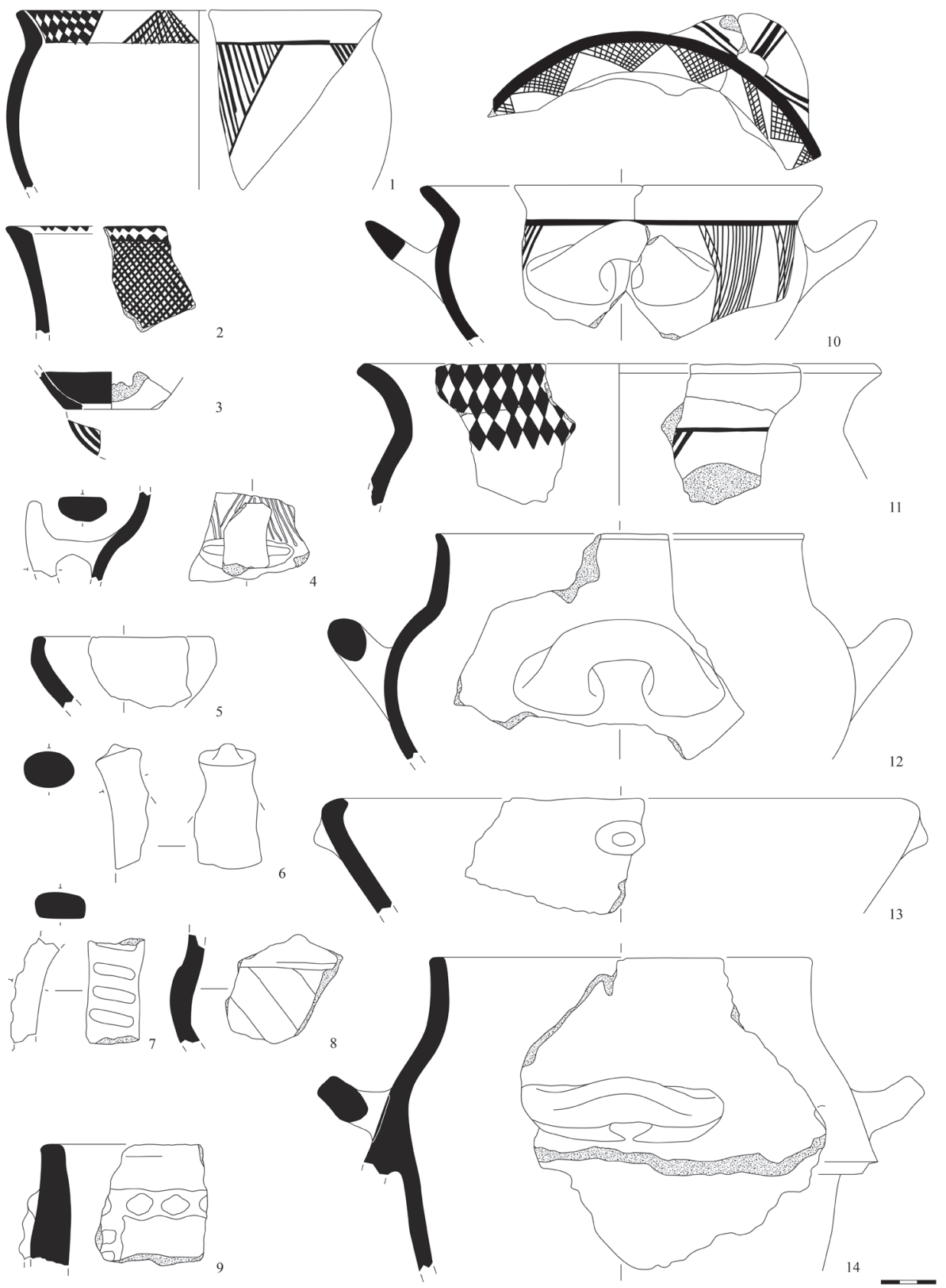

Fig. 12. Pottery from levels $5 b$ and 5a: 1 (93/110.12, 5b), 2 (93/112.13, 5b), 3 (94/211.28, $5 b), 4$ (93/110.58, 5b), 5 (94/240.12, 5a), 6 (99/418.21, disturbed layer), 7 (94/244.22, 5b), 8 (99/457.12, disturbed layer), 9 (06/344.11, 5b), 10 (99/408.35, 5a/5b), 11 (06/337.10, 5a), 12 (96/338.2, 5a), $13(94 / 213.7,5 b), 14(94 / 243.33,5 a)$. 
triangles, checkerboard patterns, irregular wavy lines, grid and ladder motifs, lozenges and some more complex patterns and combinations. ${ }^{79}$ Several motifs, mostly the flame pattern and various triangles, can also be found inside the rim. The further development after Sovjan level 5 a can be seen in Maliq IVb, at Drenova and Symize ${ }^{80}$ and in the tumuli. Curvilinear motifs, for instance, except the irregular wavy line (Fig. 13.1), are not yet present in Sovjan $5 \mathrm{~b}$ and $5 \mathrm{a}$.

Alongside matt painted pottery, channelled ware occupies a significant place in the EIA assemblages of Sovjan as well. In contrast to the matt painted ware, this type of decoration is much more widespread in Albania and is also popular in the North of the modern country. ${ }^{81}$ Best known are the turban dishes (Fig. 13.13), but there are also deeper bowls with a marked shoulder (Fig. 12.8 and 13.7), bowls with in-turned rim and horizontal grooves on their shoulder (Fig. 13.14) and even channelled handles (Fig. 12.7 and 13.8). Bowls with in-turned rim become generally very popular (Fig. 12.5 and 13), accompanied by bowls with unpronounced profile (Fig. 13.11). As mentioned above, the incised ware is still used (Fig. 12.4) but in much lower percentages than the matt painted ware. Finger impressed bands are no longer simply horizontal, but also vertical and curvilinear and different bands can intersect (Fig. 12.9).

Kantharos handles developed in levels $5 \mathrm{~b}$ and $5 \mathrm{a}$ their final form with the typical EIA upper termination (Fig. 12.6 and 13.6), but the impressions and perforations on the handles disappear. There are also kantharoid jars (Fig. 13.9). As in level 5c1, kantharoi can have small lugs between the two handles. Bowls have often their largest diameter on the everted rim (Fig. 13.3), but there are also types with spherical body and a relatively high vertical neck (Fig. 12.12). Jugs become more important during the EIA, as they are clearly attested in several fragments, and there are also some bridge-spouted vessels (Fig. 13.10). Several vases now acquire ring bases (Fig. 13.4) or even a foot (Fig. 13.5), a feature that was not yet present in level $5 \mathrm{c} 1$. In general, the fabric is of inferior quality compared to the LBA and feels rather sandy. Partially this might be due to the conditions of preservation. Fine and semifine wares sometimes bear a light slip. In coarse ware, there is a new characteristic grey fabric with a large quantity of large silver mica inclusions, used for the manufacture of storage jars and even a two-legged pyraunos that has been found at the Great Prespa Lake. ${ }^{82}$

\footnotetext{
79 Cf. Lera - Prendi - Touchais (1996) pp. 1014-1015 fig. 10-11.

80 The authors owe many thanks to P. Lera for discussing his drawings of the pottery of the last two sites. See Lera (1992) and Korkuti - Petruso (1993) p. 712.

81 E.g. Bunguri (2010) pl. XCV (Topojan, Pesjakë, Manasdren and Grevë).

82 KRAPF (forthcoming).
} 

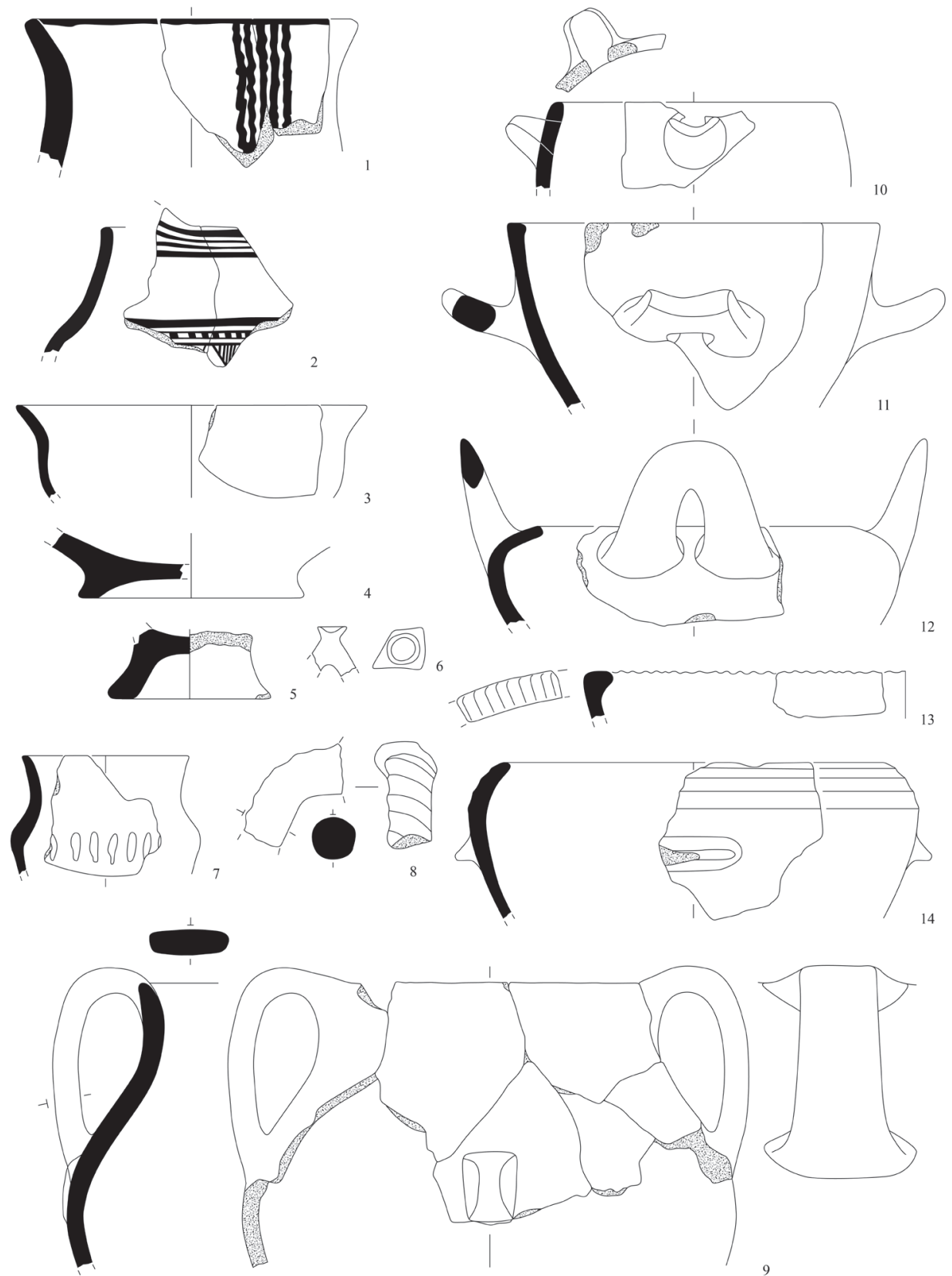

Fig. 13: Further EIA pottery fragments: 1 (90 1/5 no. 19), 2 (91 6/7 no. 106), 3 (90 1/2 no. 4), 4 (91 3/6 no. 22), 5 (91 3/10 no. 230), 6 (91 3/11 no. 129), 7 (91 5/14 no. 180), 8 (91 4/14 no. 213), 9 (90 1/12 no. 79), 10 (90 1/3 no. 6), 11 (91 4/13 no. 207), 12 (91 3/10 no. 127 ), 13 (91 6/11 no. 235), 14 (91 5/14 no. 180). 
This fabric, however, never reached the popularity of the common traditional coarse ware. Pyraunoi (Fig. 12.14) are still being used, as in Central Macedonia, but less frequently than during the LBA.

The importation of a limited number of Aegean vessels did not cease with the end of the Bronze Age and there is a handful fragments of imported EIA vessels (Fig. 12.3), reaching down to the Protocorinthian period. ${ }^{83}$

After level 5a, Sovjan was abandoned due to the rising water level of the lake, around 700 BCE. Nearby Maliq suffered the same destiny, possibly a bit later, during the Archaic period. ${ }^{84}$

\section{Conclusion}

Thanks to a reliable stratigraphic sequence combined with radiocarbon dating and a thorough pottery analysis, about 60 years after the first excavation of Maliq it is finally possible to provide a new chronological and cultural framework for the Bronze Age and the Iron Age of SE Albania. Pottery typology for Sovjan, indeed, covers ca. 1500 years and nine distinct levels, from 9 to 5a. Stratigraphic and typological sequences for Sovjan therefore allow tracing the development of a local community and its material culture over a long period of time. Pottery assemblages indicate periods of continuity and moments of change, as like as contacts with neighbouring regions. It is interesting to observe that the discontinuities in pottery production do not correspond to interruptions in stratigraphy and dwelling structures.

The presence of several excavated Bronze Age and Early Iron Age sites around the Korça Basin contributes to a detailed understanding of local cultural developments in pottery production and consumption in this area. Many shapes used during EBA are clustered in Macedonia, most characteristic among them the so-called smoking pot, which can be considered typical of Macedonia at the end of the EBA. While in the EBA very little local shapes are known and pottery production appear to be stylistically and technologically very close to the productions of the larger Macedonian region, in later periods stylistic and technological features appear to be more frequently characterised locally. Triple perforations or impressions on the handles of unpainted kantharoi during the LBA (Sovjan levels 5c2 and $5 \mathrm{cl}$ ) and a local style of matt painted pottery during the EIA appear to be characteristics of the Korça region. These features unite the Korça plain in the LBA and the transition to the EIA with the Ohrid and Prespa lakes region.

Pottery networks connecting the Korça region to more distant areas are indicative for the region's entanglement into wide and complex cultural webs. The most outstanding

83 Lera - Oberweiler - Touchais (2010) p. 45 fig. 9. 
examples of such networks are tankards of the EBA with globular bodies and cylindrical necks that connect the Korçë Basin to the Carpathian area and the Greek mainland. When EBA networks and connectivity declined, Sovjan's contacts with far-away regions shrunk. Foreign influences increased again towards the LBA and EIA. In the LBA to EIA pyraunoi cooking pots or the EIA channelled ware are elements with a wide distribution. It is interesting to note that some of these LBA features were adopted immediately, others, however, with a significant delay. An example of the latter is the matt painted pottery that had not become common before the EIA (Sovjan level 5b). A shape that seems to have changed constantly over time and therefore represents a good chronological and cultural indicator, is that of the kantharoi. The position and type of their handles are subject to changes and the different plastic enhancements on their tops during the LBA and EIA are especially helpful.

During the second half of the EBA decoration is poor and limited to fingernail impressions and plastic cordons, as like as in the wider Macedonian region. Only during the LBA decoration became more varied and hence became a good indicator for chronology and cultural contacts: new styles appeared gradually, first incisions, then matt painting and channelling.

Sovjan's stratigraphy and chrono-cultural determination has proved fundamental to re-evaluating Maliq's sequence, which has already been challenged several times during the last decades. ${ }^{85}$ As for Sovjan, it is thus possible to infer for Maliq the existence of a gap corresponding to the first phase of the Early Bronze Age. ${ }^{86}$ Furthermore, Zh. Andrea's reattribution of Maliq's later phases based on the excavation in sector $\mathrm{C}^{87}$ can be confirmed thanks to the parallel developments at Sovjan.

The fact that these chrono-cultural developments can be traced over 9 levels makes Sovjan an outstanding reference for the entire region. This study underlines once more the importance of the Korça Basin and of whole south-eastern Albania for both the southwestern Balkan and the north-western Aegean prehistory.

New research perspectives are focusing on technological analysis and provenience studies. At present we are undertaking a trial study applying portable XRF technology to assess chemical composition of BA and EIA pottery in collaboration with O. Ch. Aslaksen

\footnotetext{
84 Andrea (2009) p. 39.

85 The new attributions according to Andrea (2009) on the base of the sector C excavation seems to correspond well to the results from Sovjan.

86 Gori (2015a) pp. 187-193.

87 Andrea (2009).
} 
(University of Gothenburg). ${ }^{88}$ It is much to be hoped that the study of Sovjan's pottery will suggest new insights into the life of these prehistoric communities.

88 O. Aslaksen, M. Gori and T. Krapf, Characterising Bronze and Early Iron Age ceramics of Sovjan (SE Albania) with the use of pXRF-scanning, Poster presented at the $41^{\text {th }}$ International Symposium on Archaeometry, Kalamata 15-21 May 2016. Financial support for the analysis was generously offered by the Bank of Sweden Tercentenary Foundation. 


\section{Bibliography}

Aliu 1984

S. Aliu, Tuma e Prodanit, Iliria 1984, pp. 27-67.

Aliu 2004

S. Alıu, Tuma e Luarasit, Tirana: Botimi i Akademisë së Shkencave, 2004.

Allen - GJipali 2014

S. Allen and I. Gjipali, New Light on the Early Neolithic Period in Albania: the Southern Albania Neolithic Archaeological Project (SANAP), 2006-2013, in: L. PËrzhita, I. GJIPALI, G. Hoxha and

B. Muka (eds.), International Congress of Albanian Archaeological Studies, 65th Anniversary of Albanian

Archaeology, Tirana: Center for Albanian Studies, Institute of Archaeology, 2014, pp. 107-119.

ANDREa 1985

Zh. ANDrea, Kultura ilire e tumave nëpellgun e Korçës, Tirana: Akademia e Shkencave e RPSSH, 1985. ANDREa 2009

Zh. Andrea, Shtresat me qeramike te pikturuar te stilit devollit ne sektorin $\mathrm{C}$ te vendbanimmit prehistorik te Maliqit (germime te viteve 1988-90), Iliria 32, 2009, pp. 5-58.

Aslanis 1985

I. Aslanis, Kastanas. Die frühbronzezeitlichen Funde und Befunde, Berlin: Wissenschaftsverl. Spiess, 1985.

BODINAKU 1995

N. Bodinaku, The Late Bronze Age Culture of Albania and the Relations with the Balcanic and Aegean-Adriatic Areas, in: B. Hänsel (ed.), Handel, Tausch und Verkehr im bronze- und früheisenzeitlichen Südosteuropa. Berlin: Seminar für Ur- und Frühgeschichte der Freien Universität, 1995, pp. 259-268.

BRÄUNING - KILIAN-DiRLMEIER 2013

A. Bräuning and I. Kilian Dirlmeier, Die eisenzeitlichen Grabhügel von Vergina. Die Ausgrabungen von Photis Petsas 1960-1961, Mainz: Verlag des Römisch-Germanischen Zentralmuseums, 2013.

Bunguri 2010

A. Bunguri, Prehistoria e Dibrës. Tirana: Qendra e Studimeve Albanologjike, Instituti i Arkeologijsë, 2010.

Christmann 1996

E. Christmann, Die frühe Bronzezeit. Deutschen Ausgrabungen auf der Pevkakia-Magula in Thessalien 19671977. II, Bonn: Habelt, 1996. 
FisGHL - Kiss - Kulasar (1997)

K. P. Fischl, V. Kiss and G. Kulasar, A hordozható tủzhelyek használata a Kárpát- medencében

I. Középső bronzkor (The use of portable stoves in the Carpathian Basin I. The Middle Bronze Age), in: Momos 1, 1997, pp. 163-193.

GORI 2015a

M. Gori, Along the Rivers and Through the Mountains. A reviewed chrono-cultural framework for the southwestern Balkans during the late $3^{\text {rd }}$ and early $2^{\text {nd }}$ millennium $B C E$, Universitätsforschungen zur

Prähistorischen Archäologie, Bonn: Habelt, 2015.

GORI 2015b

M. Gori, The Long Journey of a Few Ugly Pots. Long Distance Cultural Interactions in Southwestern Balkans at the End of the Early Bronze Age, in: P. Suchowska-Ducke and H.

Vandkilde (eds.), Mobility of Culture in Bronze Age Europe, Oxford: BAR Int. Series, 2015, pp. 179 188.

Heurtley 1939

W. A. Heurtley, Prehistoric Macedonia, An archaeological reconnaissance of Greek Macedonia (West of the Struma) in the Neolithic, Bronze, and Early Iron Ages, Cambridge: University Press, 1939.

Hochstetter 1984

A. Hochstetter, Kastanas. Ausgrabungen in einem Siedlungshügel der Bronze- und Eisenzeit Makedoniens, 1975-1979. Die handgemachte Keramik, Schichten 19 bis 1, Prähistorische Archäologie in Südosteuropa 3, Berlin: Verlag Volker Spiess, 1984.

Horejs 2007

B. Horejs, Das prähistorische Olynth. Ausgrabungen in der Toumba Agios Mamas 1994-1996. Die spätbronzezeitliche handgemachte Keramik der Schichten 13 bis 1, Prähistorische Archäologie in Südosteuropa 21, Rahden: Verlag Marie Leihdorf, 2007.

Hristova 2011

R. Hristova, Late Bronze Age Pottery from the Site of Vratitsa, Eastern Bulgaria: Definition, Chronology and its Aegean Affinities, Aegean and Balkan Prehistory wrew.aegeobalkanprehistory.net/article.php?id_art=19, 2011.

KoRkuti 1971

M. Korkuti, Vendbanimi prehistorik i Trenit, Iliria 1, 1971, pp. 31-47.

Korkuti - Petruso 1993

M. Korkuti and K. M. Petruso, Archaeology in Albania, American Fournal of Archaeology 97 (4), 1993, pp. 703-743.

KRAPF 2014a

T. KRAPF, Interaction entre production locale et influences externes: le cas de la céramique du Bronze Récent de la Grèce du Nord et de l'Albanie du Sud, in: S. Ferjani, A. Le Bihan, M. Onfraiy and C. Trémeaud (eds.), Matières premières et gestion des ressources, actes de la $7^{\mathrm{e}}$ journée doctorale d'archéologie, Paris, 23 mai 2012, Archéo.doct 6, 2014, pp. 235-254. 
KRAPF 2014b

T. Krapf, The Late Bronze Age Pottery of Macedonia: Comparisons with the Plain of Korçë, in: E. Stefani, N. Meroussis and A. Dimoula (eds.), A Century of Research in Prehistoric Macedonia, 1912-2012, International Conference Proceedings, Archaeological Museum of Thessaloniki 22-24 November 2012, Thessaloniki: Archaeological Museum, 2014, pp. 585-597.

KRAPF (forthcoming) Sovjan (Korçë)

First remarks about the Late Bronze Age pottery, in: G. Karamitrou-Mentesidi (ed.), To archaiologiko ergo stin Ano Makedonia 3, 2013, forthcoming.

LERA 1990

P. Lera, Sovjan (Korçë), Iliria 1990, 250-252.

LERA 1992

P. Lera, Vendbanimi ilir ne gradishten e Symizes, Iliria 1992, pp. 177-208.

Lera - Prendi - Touchais 1996

P. Lera, F. Prendi and G. Touchais, Travaux menés en collaboration avec l'École française d'Athènes en 1995. Sovjan (Albanie), Bulletin de Correspondance Hellénique 120 (2), 1996, pp. 9951026.

LERA - TOUGHais 1997

P. Lera and G. Touchais, Travaux menés en collaboration avec l'École française d'Athènes en 1996. Sovjan (Albanie), Bulletin de Correspondance Hellénique 121 (2), 1997, pp. 871-879.

LERA - TOUGHAIS 2000

P. Lera and G. Touchais, Travaux menés en collaboration avec l'École française d'Athènes en 1999. Sovjan (Albanie), Bulletin de Correspondance Hellénique 124 (2), 2000, pp. 631-642.

LERA - TOUGHAIS 2002

P. Lera and G. Touchais, Travaux menés en collaboration avec l'École française d'Athènes en 2001. Sovjan (Albanie), Bulletin de Correspondance Hellénique 126 (2), 2002, pp. 627-645.

LERA - TOUChais 2003

P. LERA and G. Touchais, Travaux menés en collaboration avec l'École française d'Athènes en 2002. Sovjan (Albanie), Bulletin de Correspondance Hellénique 127 (2), 2003, pp. 578-609.

Lera - TOughais 2004

P. Lera and G. Touchais, Le Bronze Moyen dans le bassin de Korçë à la lumière des fouilles de Sovjan, in: P. Cabanes and J. L. Lamboley (eds.), L'Illyrie méridionale et l'Épire dans l'Antiquité IV, Act. coll. Grenoble, 10-12 oct. 2002, 2004, pp. 23-38.

LERA - TOUCHAIS 2004-5

P. Lera and G. Touchais, Travaux menés en collaboration avec l'École française d'Athènes en 2003. Sovjan (Albanie), Bulletin de Correspondance Hellénique 128-129, 2004-5 (2.1), pp. 1096-1147. 
Lera - Toughais - OberweILer 2009

P. Lera, G. Touchais and C. Oberweiler, Travaux de l'École française d'Athènes en 2008. Bassin de Korçë, Kallamas, Bulletin de Correspondance Hellénique 133, 2009, pp. 689-724.

LERA - OBERWEILER - TOUGHAIs 2010

P. Lera, C. Oberweiler and G. Toughais, Le passage du Bronze Récent au Fer Ancien sur le site de Sovjan (Bassin de Korçë, Albanie): Nouvelles données chronologiques, in : J.-L. Lamboley and M. P. Castiglioni (eds.), L'Illyrie méridionale et l'Épire dans l'antiquité V, Actes du Ve colloque international de Grenoble, 10-12 octobre 2008, Pars: De Boccard, 2010, pp. 41-52.

Lera - Toughais - OberweILER 2012-3

P. Lera, G. Touchais, C. Oberweiler in collaboration with A. Boletti, C. Cheval, R. Christidou, M. Gori, T. Krapf, C. Revellat and R. Ruka, Travaux de l'École française d'Athènes en 2011. Bassin de Korçë, Kallamas, Bulletin de Correspondance Hellénique 136-137, 2012-2013, pp. 687-722.

Morris 2011

S. P. Morris, Proistoriki Toroni (1986-1990) : prokatarktika apotelesmata ton anaskafon sti thesi « Likythos » (Prehistoric Toroni (1986-1990): Preliminary results of the excavations at the site « Likythos »), Archaiologiko Ergo Makedonias kai Thrakis 22, 2008, pp. 435-442.

OBerweILER - TOUGhais - Lera 2014

C. Oberweiler, G. Touchais and P. Lera, Les recherches franco-albanaises dans la région de Korçë nouvelles données sur la chronologie absolue de la préhistoire albanaise, in: L. Përzhita, I. Gjipali, G. Hoxha and B. Muka (eds.), International Congress of Albanian Archaeological Studies, 65th Anniversary of Albanian Archaeology, Tirana: Center for Albanian Studies, Institute of Archaeology, 2014, pp. 82-92.

Papadopoulos - Morris - Bejko - Schepartz 2014

J. K. Papadopoulos, S. P. Morris, L. Bejko and L. A. Schepartz, The Excavation of the Prehistoric Burial Tumulus at Lofkënd, Albania, Monumenta Archaeologica 34, Los Angeles: Cotsen Institute of Archaeology Press, 2014.

Papaefthimiou Papanthimou - Pilali Papasteriou 2002

A. Papaefthimiou-Papanthimou and A. Pilali-Papasteriou, Archontiko 2000, Egnatia 6, 2002, pp. 307-316.

Prendi 1966

F. Prendi, La civilisation préhistorique de Maliq, Studia Albanica 3, 1966, pp. 255-280.

PRENDi 1982

F. Prendi, Die Bronzezeit und der Beginn der Eisenzeit in Albanien, in: B. Hänsel (ed.), Südosteuropa zwischen 1600 und 1000 v. Chr., Berlin: Moreland Editions, 1982, pp. 203-233.

Prendi - Bunguri 2008

F. Prendi - A. Bunguri, The Early Bronze Age in Albania, Prishtina: The Albanological Studying Center, The Institute of Archaeology. 
RUTTER 1995

J. B. Rutter, The pottery of Lerna IV, Princeton: The Am. Sch. o. Cl. St. at Ath., 1995.

TOUCHAIS - Lera 2007

G. Touchais and P. Lera, L'Albanie méridionale et le monde égéen à l'Âge du Bronze : Problèmes chronologiques et rapports culturels, in: I. Galanakis, Y. Galanakis and R. Laffineur (eds.),

Between the Aegean and Baltic Seas : Prehistory Across Borders. Proceedings of the International Conference, Zagreb, 11-14 April 2005, Aegaeum 27, 2007, 141-147. 


\section{PËRMBLEDHJE \\ QERAMIKA E KOHËS SË BRONXIT DHE TË HEKURIT NGA SOVJANI}

Sovjani ndodhet në Shqipërinë Juglindore, në pjesën veriperëndimore të Pellgut të Korçës. Ai është një vendbanim liqenor me një sipërfaqe prej 1.5 ha dhe shtrihet rreth $3.5 \mathrm{~km}$ në verilindje të fshatit të sotëm të Maliqit. Sekuenca stratigrafike e Sovjanit shtrihet nga periudha e Neolitit të Hershëm deri në periudhën e Hekurit. Në gjendjen aktuale ai përbën të vetmin vendbanim në Ballkanin jugperëndimor të gjysmës së dytë të Bronzit të Hershëm për të cilin janë në dispozicion një numër i konsiderueshëm datimesh absolute dendrokronologjike dhe me C14.

Niveli 14 është shtresa sterile nën depozitat më të hershme antropogjenike. Nivelet 13 dhe 12 datohen të dy në Neolitin e Hershëm. Niveli 11 daton në Neolitin e Hershëm ose të Mesëm ndërsa niveli 10 nuk ka dhënë material arkeologjik. Niveli 9 përbën nivelin më hershëm të periudhës së Bronzit në vendbanim (3935 \pm 30 para / 2486 deri në 2204 para Kr.). Niveli i 8-të përbëhet nga një shtresë torfe ngjyrë kafe e pasur në materiale organike. Vetëm një datim me C14 është në dispozicion nga kjo shtresë i cili daton nga $3765 \pm 45$ para/ 2303 deri në 2040 para Kr. Niveli 8 përmban strukturat më të rëndësishme dhe më të ruajtura të banesave prej druri të Bronzit të Hershëm të njohura deri më sot në Ballkanin jugperëndimor. Struktura më e veçantë është quajtur Maison du Canal. Në krahasim me nivelin 8 , shumë pak elemente njihen nga niveli 7 , kronologjia e të cilit paraqitet problematike. Në fakt, një datim nga ky nivel (4035 \pm 55 para / 2843 deri në 2416 para Kr.) është identik ose ndoshta dhe më i vjetër se datimi me radiokarbon nga niveli 9, ndërsa datimet e tjera (2300 deri në 1950 para Kr.) janë të krahasueshme me datimin e vetëm me radiokarbon nga niveli 8. Niveli 6 korrespondon me një shtresë nivelimi dhe mbushjeje e cila paraprin instalimin e dyshemeve të periudhës së Bronzit të Vonë. Dy datimet me radiokarbon në dispozicion nga fundi i nivelit 6 i mbivendosen nivelit 7, dhe një përzirje me nivelin 7 nuk mund të përjashtohet plotësisht. Nivelet e periudhës së Bronzit të Vonë 5c1, 5c2 dhe 5c3 përputhen me tre nivelet e banimit (S2, S3 dhe S4). Datimit me radiokarbon e vendosin nivelin 5c1 
midis 1400 dhe 1000 para Kr., 5c2 midis 1430-1225 para Kr., dhe 5c3 midis 1603-1322 para Kr. Nivelet 4, 5a dhe 5b si dhe një strukturë banimi lidhen me periudhën e Hekurit. Niveli 4 është një sediment torfe dhe përputhet me braktisjen e Sovjanit si rrjedhojë e rritjes së nivelit të ujit. Datimet me radiokarbon e vendosin nivelin 4 në një horizont kronologjik më të vonë, midis 527-214 dhe 50-180 pas Kr. Nivelet 3 dhe 2 janë depozita të akumuluara në fund të liqenit, ndërsa niveli 1 përbëhet nga mbushjet prej ndërtimit të kanalit të kullimit.

Teknologjia : Qeramika nga nivelet e periudhave të Bronzit dhe të Hekurit të Hershëm është e gjitha e prodhuar me dorë, shpesh duke përdorur teknikën me shirita (coiling). Përjashtim përbëjnë një numër i vogël enësh importi të prodhuara çark, të cilat shfaqen në Sovjan duke filluar nga niveli 5cl. Teknikat e prodhimit të para me sy të lirë janë mjaft homogjene, por disa veçori teknike si p. sh. një boshti të dalë prej balte (clay pivot) $\mathrm{i}$ përdorur për ngjitjen e vegjes, vihen re vetëm në qeramikën e Bronzit të Vonë, ndërsa në Bronzin e Hershëm vegjet thjesht shtypeshin në sipërfaqen e enës (Fig. 3). Ndryshime të tjera të veçorive teknologjike lidhen me teknologjinë e pjekjes. Qeramika e niveleve të Bronzit të Hershëm piqej në zjarre të hapura në atmosferë reduktive, ç'ka sillte si rezultat një ngjyrë karakateristike e zezë në gri të sipërfaqes dhe të prerjes. Duke filluar nga niveli 7, por më dukshëm në nivelet 6 dhe 5, teknikat e pjekjes pësojnë disa ndryshime dhe sipërfaqja dhe prerja bëhen më të çelura dhe më shpesh të kuqërremta. Qeramika nuk është pikturuar në asnjë rast para nivelit $5 \mathrm{c} 1$, por shpesh zbukurohet me sekuenca dekori impreso, me elemente të dekorit plastik si pika ose shirita, dhe rastësisht me inçizim dhe hulli. Lëmimi përbën teknikën kryesore të trajtimit të sipërfaqes ndërsa teknikat e tjera përdoreshin rrallë dhe duhet të përmendim këtu rastet e ralla kur një cipë aplikohej në sipërfaqen e enës. Mungesa e një formule standarte të baltës dhe përdorimi i përzierjeve të ndryshme me gjeologji të njëjtë, e bëjnë të pamundur identifikimin e grupeve të qeramikës, veçanërisht për nivelet 9 , 8, 7 dhe 6 . Ndryshime në cilësi mund të vihen re vetëm për nivelin 5c3, kur shfaqet një seri e re me qeramikë fine e cila është tipike për qeramikën e Bronzit të Vonë. Ky zhvillim vazhdon deri në fund të periudhës së Bronzit të Vonë në nivelin 5c1, ndërsa cilësia bie përsëri gjatë periudhës së hershme të Hekurit. Gjithsesi, pak përbërje të reja të baltës mund të dallohen në nivelet $5 \mathrm{~b}$ dhe $5 \mathrm{a}$.

Niveli 9 (Fig. 4): Për fat të keq, nuk ka elemente të dallueshëm tipologjikë që të dallojnë qartë grupin e vogël të qeramikës të nivelit 9 nga ato të niveleve 8 dhe 7 . Të vetmet tipe të veçantë për nivelin 9 janë kantarët pa qafë të dallueshme (tipi C.c.i. 1 varianti b, Fig. 4.1) dhe filxhanët me profil në formë S-je dhe buzë të kthyera (tipi B.a.ii.2, varianti a, Fig. $4.2)$.

Niveli 8 (Fig. 5): Grupi i qeramikës nga niveli 8 ka pak elementë tipologjikë të dallueshëm. Ndërsa tasat e Sovjanit paraqesin gjatë gjithë kohës ndryshime të vogla tipologjike duke pasqyruar një konservatorizëm të theksuar, format e kupave (beaker) 
dhe filxhanëve (cup) ndryshojnë relativisht shpejt nga njëra fazë në tjetrën dhe mund të kosiderohen si tregues kronologjikë. Një sërë tipesh të filxhanëve dhe kupave janë të veçantë për nivelin 8: filxhanët me trup në formë vezake dhe vegje vertikale në formë shiriti në pikën e zgjerimit maksimal të trupit (typi B.b.1., Fig. 5.1), filxhanë me profil jo të ndryshueshëm dhe parete të drejtë (unicum B.a.i. $\alpha .4$, Fig. 5.2), filxhanë me trup globular dhe buzë të thjeshta e të kthyera (tipi B.b.6 varianti $a$, Fig. 5.3), si dhe kupa me profil të vazhdueshëm dhe mure të drejtë (tipi B.a.i.a.1, Fig. 5.4). Në të kundërt, i vetmi tip kantari karakteristik për këtë nivel ka një trup afërsisht bikonik (C.a.3 varieti $a$, Fig. 5.5). Qeramika nga niveli 8 krahasohet me shembuj nga Kastanas Schicht 27, Kritsanà Siedlung III dhe Sitagroi Vb. Gjithsesi, shembujt që i përkasin tipit B.b.6 mund të krahasohen me filxhanët e grupit Belotić Bela Crkva nga Serbia qëndrore, dhe me tasat Bass të prodhuar me qeramikë fine të lustruar me ngjyrë gri e cila shpërhapet në Egje gjatë Heladikut të Hershëm III. Brokat (tankard) me trup afërsisht bikonik (tipi C.a.3, varianti a) janë të lidhur ngushtë me brokat e tipit C.a.2 (variant a, Fig. 5.6) të gjetur si në nivelin 8 dhe 7. Këto tipe e lidhin Sovjanin si me grupin Belotić Bela Grkva dhe me Egjeun. Brokat C.a.2 (varianti b, Fig. 5.7) shfaqin ngjashmëri midis nivelit 8 dhe gjetjeve të fazës proto-Cetina në Dalmaci. Vorba të vogla me trup thuajse globular (tipi

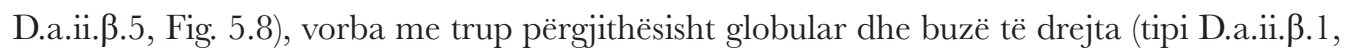
varianti $a$, Fig. 5.9) dhe vorba me trup përgjithësisht globular dhe buzë të kthyera (type D.a.ii.p.2 variety $a$, Fig. 5.9) janë dokumentuar vetëm në nivelin 8 së bashku me vorba të vogla me qafë afërsisht cilindrike (tipi D.b.iv.2 varianti $c$, Fig. 5.10), vorba me qafë të gjatë e cila vjen duke u ngushtuar sipër dhe që hapet drejt buzës (tipi D.b.iv.5, Fig. 5.11), vorba të vogla me trup të zgjatur (unicum D.b.iv.9), dhe me vorba të vogla me qafë të ngushtë e cila vjen duke u hapur (tipi D.b.iv.10).

Niveli 7 (Fig. 6): Në nivelin 7, tasat me profil të artikuluar janë shumë më të numërt në krahasim me tasat me profil të vazhdueshëm. Tasat në formë kalote (tipi A.a.ii. $\beta .1$ varianti $b$, Fig. 6.1) përbëjnë të vetmin tip tasi me profil të vazhdueshëm i pranishëm vetëm në nivelin 7. Paralele tipologjike të këtyre tasave njihen jashtë Pellgut të Korçës, kryesisht në Maqedoninë Qëndrore (Kastanas) dhe në Thesali (Argissa Magoula). Në Sovjan, një tas i vetëm bikonik është dokumentuar nga niveli 7 (unicum A.b.vi.ß.1, Fig. 6.2). Prania e tasave bikonikë në kontekstet më të vona sugjeron se forma bikonike është një tregues karakteristik i një horizonti kronologjik që pason Heladikun e Hershëm III. Tasa të ngjashëm janë të pranishëm në Sveta Nedela dhe në qëndra të tjera të periudhës së Bronzit të Vonë duke përfshirë dhe tumbën e Agios Mamas në Olinth. Brokat me trup globular të tipit C.a.2 varianti a (Fig. 5.6, të dokumentuar në nivelet 8 dhe 7) së bashku me filxhanët me dy vegje me trup globular (tipi B.b.6, varianti b, Fig. 6.3) e lidhin gjithashtu nivelin 7 të Sovjanit me Ballkanin Qëndror dhe Egjeun. Filxhani i tipit B.b.2 (Fig. 6.4), krahasohet gjithashtu me tipet Somogyvár-Vinkovci duke e lidhur kështu Sovjanin dhe me pjesën më lindore 
Fushës së Panonisë. Filxhanë të ngjashëm me unicum B.a.ii.3 (Fig. 6.5) dhe kantarë që të kujtojnë unicum C.a.1 (Fig. 6.6) nga niveli 7 janë gjithashtu të pranishëm në nivelet 6 dhe 5 të Sovjanit, ndërsa kupa të ngjashme me tipin C.b.1 (Fig. 6.7) janë gjetur në Sveta Nedela (tipi C.3), një vendbanim i periudhës së Bronzit të Vonë. Këto të dhëna mbështesin rëndësinë e këtyre tipeve si tregues kronologjikë për kalimin nga periudha e Hershme në atë të Mesme të Bronzit. Tre shembuj të enëve të zjarrit (tipi F.1, Fig. 6.8) janë zbuluar nga niveli 7, duke dëshmuar një rritje në krahasim me nivelin 8 , ku është gjetur vetëm një prej tyre. Ënë të krahasueshme nga kontekste të Greqisë veriore dhe Serbisë jugore tregojnë një horizont kronologjik që përkon me fundin e Heladikut III dhe fazën e parë të Heladikut të Mesëm. Mbi të gjitha, datimet me radiokarbon dhe gjetjet e qeramikës që përputhen me nivelin 7, datojnë në fundin e periudhës së Bronzit të Hershëm (Heladik i Hershëm III) dhe fillimin e periudhës së Broznit të Mesëm (Heladik i Mesëm I).

Niveli 6 (Fig. 7): Format e qeramikës ende mbështeten kryesisht në traditën e nivelit 7: p. sh. legen (bassins) të mëdhenj prej qeramike trashanike me brima poshtë buzës (Fig. 7.1) ose vegje në trajtë bollunge nga brenda dhe jashtë enës (Fig. 7.2). Një zhvillim i dukshëm teknologjik i cili mbështetet nga rënia e enëve të pjekura në atmosferë të reduktuar dhe futja e vegjeve të ngulitura ne siperfaqen e enes, si dhe shfaqja për herë të parë dhe pa dyshim në raste të rralla i fenomeneve tipikë të Bronzit të Vonë të tillë si pyraunos-i i parë në një kontekst të sigurt (Fig. 7.10, dyshemeja S4), e lidhin nivelin 6 me nivelet që pasojnë të Bronzit të Vonë. Por një ndryshim i theksuar në taksonomi do të bëhet i dukshëm vetëm në nivelet 5c3 to 5c2. Ashti si edhe në Bronzin e Hershëm vegjet shiritore janë rrethore (Fig. 7.12) dhe kur vendosen në buzë ato dalin shumë pak mbi të (Fig. 7.7). Eshtë për tu përmendur një kantar i plotë me baltë gri me vegje të larta dhe me profil në formë S-je, i gjetur në fund të nivelit 6 . Kantarë të tillë janë gjetur në Maliq IIIc bashkë me vegje unazore vertikale të vendosura në pjesën e belit dhe janë konsideruar si tipikë për periudhën e Mesme të Broznit. Profilet e enëve janë zakonisht të rrumbullakosura dhe më pak të artikuluara se në horizontet pauses, dhe bazat janë kryesisht të sheshta (Fig. 7.8), duke u dalluar gjithashtu nga ato të fazave pasuese. Përbërja e baltës është gjithmonë e ashpër ose gjysëm e ashpër dhe e vetmja mënyrë për të dalluar enët e tavolinës është sipërfaqja e tyre e lëmuar. Dekori konsiston vetëm në shirita plastikë horizontalë, të thjeshtë ose me dekor me shtypje (Fig. 7.6) dhe në breza impreso të thjeshtë në pjesën e sipërme të enëve. Shtypjet në vegjet bullungë (lug handles) (Fig. 7.5) janë një risi e nivelit 6 ndërsa buzët janë më shpesh të zbukuruara me impreso në nivelet 6 dhe 5c3 se në fazat më të vona (Fig. 7.4). Këto kakarakteristika dëshmojnë për lidhjen e fortë midis nivelit 7 dhe 6. Prania paralele e elementëve të parë të Bronzit të Vonë e bëjnë gjithsesi të besueshme, të paktën pjesërisht, lidhjen me këtë periudhë. Niveli 6 duhet të mbulojë gjithashtu një pjesë të periudhës së mëparshme të Bronzit të Mesëm, veçanërisht nëse datimi i hershëm me C14 nga fillimi i nivelit 5c3 do të rezultojë të 
jetë i saktë. Paralelet me Maliqin IIIc e përforcojnë më tej këtë hipotezë.

Niveli 5c3 (Fig. 8): Përsa i përket stileve të qeramikës kultura e periudhës së Bronzit të Vonë fillon pa dyshim në nivelin 5c3. Risinë kryesore e përbën qeramika gjysëm fine, tradicionalisht në ngjyrë gri por dhe me baltë kafe në portokalli. Tipikë janë kantarët me vegje të larta dhe tasat në formë S-je dhe vegje horizontale, si rrethore (Fig. 8.2) dhe të tipit wishbone (Fig. 8.4 dhe 5, ndoshta gjithashtu dhe 11). Tipi i dytë duket të jetë më i shpeshtë në nivelin 5c3 por shfaqet gjithashtu dhe në nivelet më të vona. Sipas F. Prendit, shfaqja e vegjeve wishbone në Maliq IIIb dhe IIIc është problematike në krahasim me Sovjanin, ku ato janë qartësisht një tipar i periudhës së Bronzit të Vonë. Vegjet e kantarëve janë të një tipi më të thjeshtë se në nivelin 5c2, pa zgjatime apo hulli në kulmin e tyre (Fig. 8.3 dhe 6). Po ashtu, tipikë për nivelin 5c3 janë tasat me vegje bullungë të vegjël të brimuar horizontalisht (Fig. 8.12). Pyraunoi (Fig. 8.7) tani përbëjnë një formë të shpeshtë në repertorin e qeramikës por janë larg të qënurit të zakonshëm si në nivelet pauses $5 \mathrm{c} 2$ dhe $5 \mathrm{c} 1$. Amforat me qafë të ngushtë plotësojnë grupin e qeramikës së periudhës së Bronzit të Vonë (Fig. 8.9). Zbukurimi i qeramikës është ende i kufizuar në dekorin me shtypje në buzë (Fig. 8.14), disa aplikime në formë gjysmë-hëne (Fig. 8.1) me shtypje si dhe brezat me shtypje me gisht dhe vegjet bullungë (Fig. 8.8).

Niveli 5c2 (Fig. 9): Në nivelin 5c2 tipologjia e qeramikës së Bronzit të Vonë është më e arrirë. Kantarët kanë vegje me zgjatime dhe hulli në kulmin e tyre (Fig. 9.1, 2 dhe 10), gjë që është tipike për një territor më të gjerë të Ballkanit Jugor. Më karakteristike është shfaqja e një ose tre brimave ose shtypjeve në pjesën e sipërme (Fig. 9.1 dhe 10). Shpimet/shtypjet treshe në kantarët e thjeshtë përbëjnë një tipar dallues për një zonë më të gjerë përreth Pellgut të Korçës dhe liqenit të Ohrit. Kantarët kanë ose formë S-je ose formë bikonike të mprehtë (carinated) me shpatulla konkave. Tasa të mëdhenj e të thellë shpesh kanë një profil të lehtë dhe jo të theksuar në formë S-je (Fig. 9.11). Dekori me incizim (asnjëherë me inkrustim përveç një rasti të vetëm) paraqitet tani në formën e motiveve të thjeshta të tilla si vijat e dallgëzuara, zigzageve dhe trekëndëshave (Fig. 9.7-8). Ky zhvillim ndodh relativisht vonë krahasuar me shfaqjen që në nivelin 19 në Kastanas të incizimeve me motive tipikë për periudhën e Bronzit të Vonë. Ashtu si dhe në nivelin 5c3, qypat e mëdhenj për depozitim janë prodhuar tashmë me një baltë thuajse fine me përzierje të mëdha kuarci dhe janë pjekur shumë më mirë se qeramika e zakonshme trashanike. Pyraunoi (Fig. 9.14), tashmë të pranishëm në numër më të madh dhe në më shumë forma, bashkë me vorbat dhe tenxheret e mëdha përbëjnë format standarte të enëve të gatimit. Shfaqja e tyre tregon një farë ndryshimi në zakonet e gatimit dhe përshtatje me një tendencë më të përgjithshme në Ballkanin jug-perëndimor. Fragmente dhe enë të plota janë publikuar vetëm nga një numër i kufizuar vendgjetjesh në Shqipëri (Kuç i Zi, Maliq dhe Prodan), por ato duhet të kenë patur një shpëndarje më të gjerë. 
Niveli 5 c1 (Fig. 10 dhe 11): Datimet me C14 mbështesin praninë e një horizonti të konsiderueshëm kronologjik të nivelit 5cl (1400-1000 para Kr.) i cili është vërtetuar dhe nga pak importe Mikenase ( $0.1 \%$ të grupit të qeramikës) që datojnë nga Heladiku i Vonë IIIB në periudhën Submikenase (Fig. 10.4). Në të njëjtën kohë fragmentet e para të qeramikës me pikturim mat shfaqen në njësi të qarta stratigrafike të nivelit 5cl (Fig. 10.6), por ky tip dekori bëhet popullor vetëm në periudhën e Hekurit të Hershëm. Një risi janë vegjet bifora të kantarëve, të cilat gjithsesi nuk shfaqen në numër të madh (Fig. 10.7). Tasat sferikë të thellë (Fig. 10.10-11) janë prodhuar me qeramikë trashanike në gjysëm fine dhe rrjedhimisht përdoreshin për punë të ndryshme, duke përfshirë dhe gatimin bashkë me pyraunoi (Fig. 11.8). Qypat me qafë të ngushtë (Fig. 11.1, 3 dhe 6-7) shfaqin një variacion të madh, nga qafa cilindrike konkave në qafa në formë hinke dhe buzë të shkurtra të kthyera. Ashtu si dhe në nivelin 5c2 (Fig. 9.9), vegjet e tyre vertikale (Fig. 11.9) ndjekin tipologjinë e vegjeve të kantarëve: ato drejtohen lart ose kanë një zgjatim dhe mund të kenë dhe një shtypje të vetme në ngjitjen e sipërme. Kjo mund të përbëjë një veçori lokale (cf. Tren, Plocha Michov Grad ose Sveta Nedela). Vegje të tilla, edhe pse më rallë, shfaqen gjithashtu në tasa të thellë dhe në filxhanë. Pak fragmente tregojnë praninë e kullesave (Fig. 11.5). Kulmi i nivelit 5c1 dallohet nga shfaqja e elementëve të Hekurit të Hershëm të tillë si enët me kanelyra, tasat me buzë të kthyera përbrenda, si dhe brezat me shtypje me gisht që nuk janë më vetëm horizontalë. Kjo periudhë kalimtare përputhet me shtresat 13 dhe 12 të Kastanasit. Ndërsa Maliqi IIId përputhet me nivelin 5c1 të Sovjanit, faza kalimtare (sipas Zh. Andrea) Maliq IVa ka një thellësi të kosniderueshme prej 0.4-0.7 m dhe mbulon jo vetëm këtë shtresë të hollë kalimtare të Sovjanit por dhe pjesë të mëdha të nivelit $5 \mathrm{~b}$.

Nivelet $\mathbf{5 b}$ dhe 5a (Fig. 12 dhe 13): Në përgjithësi mund të vihet re një vazhdimësi në traditën e qeramikës midis periudhës së Bronzit të Vonë dhe asaj të Hekurit të Hershëm. Dy nivelet e Hekurit të Hershëm 5b dhe 5a janë trajtuar këtu së bashku pasi studimi i tyre është ende në vazhdim. Këto faza janë të përfaqësuara më mirë nga fushatat e gërmimeve të viteve 1990 dhe 1991 të kryera nga P. Lera (kuadratet A3-6). Tiparin më karakteristik e përbën qeramika me pikturim mat e cila në këtë periudhë bëhet e zakonshme (Fig. 12.1-2 dhe 10-11, Fig. 13.1.2). Qeramika me kanelyra (Fig. 12.7-8, 13.7-8, 13-14) zë gjithashtu një vend të rëndësishëm në gjetjet e Hekurit të Hershëm nga Sovjani dhe në kontrast me qeramikën me pikturim mat ajo është e zakonshme dhe në veri të Shqipërisë. Tasat me buzë të kthyera përbrenda bëhen në përgjithësi shumë të zakonshëm (Fig. 12.5 and 13), të shoqëruar nga tasat me profil jo të theksuar (Fig. 13.11). Qeramika e incizuar përdoret ende (Fig. 12.4) por në përqindje më të ulët në krahasim me qeramikën me pikturim mat. Shirita me shtypje me gisht, ndonjëherë që kryqëzohen, janë horizontalë, vertikalë ose në linja të lakuara (Fig. 12.9). Vegjet e kantarëve zhvillojnë në nivelet 5b dhe 5a formën e tyre finale, me kulmin e sipërm karakteristik për periudhën e Hekurit të Hershëm (Fig. 12.6 dhe 13.6), 
por dekori me shtypje dhe brimat në vegje zhduken. Kanat bëhen më të rëndësishme gjatë Hekurit të Hershëm siç janë dëshmuar në disa fragmente si dhe ka gjithashtu disa enë me lëfyt (Fig. 13.10). Disa enë kanë në këtë periudhë një fund unazor (Fig. 13.4), apo edhe një këmbë, një veçori që nuk ka qenë e pranishme në nivelin 5c1. Në përgjithësi, balta ka cilësi të ulët krahasuar me periudhën e Bronzit të Vonë dhe është më tepër ranore. Enët fine ose gjysëm-fine ndonjëherë kanë një cipë të hollë. Ashtu si dhe në Maqedoninë Qëndrore, pyraunoi (Fig. 12.14) përdoren ende por më rrallë se në Bronzin e Vonë. Importi i një numri të kufizuar enësh Egjeane nuk ndalon me fundin e Bronzit të Vonë dhe ka një numër të vogël enësh të importuara të cilat datojnë në Hekurin e Hershëm (Fig. 12.3).

Përfundime : Sekuenca stratigrafike e Sovjanit na lejon të ndjekim zhvillimin e qeramikës nga periudha e Bronzit të Hershëm në atë të Hekurit të Hershëm, në 9 nivele të dallueshëm të cilët mbulojnë një periudhë prej rreth 1500 vjetësh. Gjatë Bronzit të Hershëm shumë forma enësh janë përdorur në një territor më të gjerë në Maqedoni (p. sh. të ashtuquajturat furra në miniaturë) dhe vetëm pak forma mund të identifikohen si lokale, ndryshe nga fazat pasuese kur stile dhe forma të veçanta karakterizojnë zonën e Korçës, Ohrit dhe Prespës. Influencat nga zona më të largëta vihen re në mënyrë të barabartë, veçanërisht gjatë Bronzit të Hershëm: brokat me trup globular dhe qafë cilindrike lidhin Pellgun e Korçës me zonën e Karpateve dhe kontinentin Grek. Kur lidhjet dhe rrjetet e komunikimit të Bronzit të Hershëm bien, kontaktet e Sovjanit me zonat e largëta tkurren. Influencat e jashtme do të rriten përsëri drejt periudhës së Bronzit të Vonë dhe asaj të Hekurit të Hershëm. Gjatë periudhës së Bronzit të Vonë dhe të Hekurit të Hershëm, enët e kuzhinës pyranuoi ose qeramika me kanelyra e Hekurit të Hershëm përbëjnë elementë me shpërndarje të gjerë. Eshte me rëndësi të theksojmë se disa nga këto tipare të Bronzit të Vonë përshtaten menjëherë, ndonëse të tjerat me një vonesë të konsiderueshme (qeramika me pikturim mat). Tregues të mirë kronologjikë dhe kulturorë janë kantarët, ndërsa pozicioni dhe tipi i vegjeve të tyre ndryshon vazhdimisht. Dekori bëhet më i larmishëm vetëm gjatë Bronzit të Vonë me shfaqjen graduale të stileve të rinj me rëndësi kronologjike. Stratigrafia e Sovjanit dhe përcaktimi krono-kulturor ka qënë themelor për ri-vlerësimin e sekuencës së vendbanimit të Maliqit, e cila është diskutuar disa herë gjatë dekadave të fundit. Rivlerësimi i fazave të vona të Maliqit nga Zh. Andrea, bazuar në gërmimin e sektorit $\mathrm{G}$, mund të konfirmohet falë zhvillimeve paralele në Sovjan. 